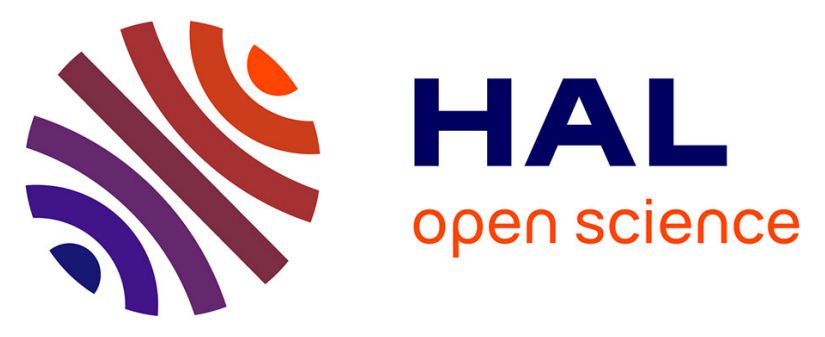

\title{
Lago Mare episodes around the Messinian-Zanclean boundary in the deep southwestern Mediterranean
}

Speranta-Maria Popescu, Mathieu Dalibard, Jean-Pierre Suc, Nadia Barhoun,

Mihaela-Carmen Melinte-Dobrinescu, Maria-Angela Bassetti, Florina

Deaconu, Martin J. Head, Christian Gorini, Damien Do Couto, et al.

\section{To cite this version:}

Speranta-Maria Popescu, Mathieu Dalibard, Jean-Pierre Suc, Nadia Barhoun, Mihaela-Carmen Melinte-Dobrinescu, et al.. Lago Mare episodes around the Messinian-Zanclean boundary in the deep southwestern Mediterranean. Marine and Petroleum Geology, 2015, 66, pp.55-70. 10.1016/j.marpetgeo.2015.04.002 . hal-01256850

\section{HAL Id: hal-01256850 https://hal.science/hal-01256850}

Submitted on 15 Jan 2016

HAL is a multi-disciplinary open access archive for the deposit and dissemination of scientific research documents, whether they are published or not. The documents may come from teaching and research institutions in France or abroad, or from public or private research centers.
L'archive ouverte pluridisciplinaire HAL, est destinée au dépôt et à la diffusion de documents scientifiques de niveau recherche, publiés ou non, émanant des établissements d'enseignement et de recherche français ou étrangers, des laboratoires publics ou privés. 


\title{
Lago Mare episodes around the Messinian-Zanclean boundary in the deep southwestern Mediterranean
}

\author{
Speranta-Maria Popescu ${ }^{1 *}$, Mathieu Dalibard ${ }^{1}$, Jean-Pierre Suc ${ }^{2,3}$, Nadia Barhoun ${ }^{4}$, \\ Mihaela-Carmen Melinte-Dobrinescu ${ }^{5}$, Maria Angela Bassetti ${ }^{6}$, Florina Deaconu ${ }^{1}$, \\ Martin J. Head ${ }^{7}$, Christian Gorini ${ }^{2,3}$, Damien Do Couto ${ }^{8}$, \\ Jean-Loup Rubino ${ }^{9}$, Jean-Luc Auxietre ${ }^{10}$, Jonathan Floodpage ${ }^{10}$
}

1, GeoBioStratData Consulting, 385 Route du Mas Rillier, 69140, Rillieux la Pape, France

2, Sorbonne Universités, UPMC Univ. Paris 06, UMR 7193, Institut des Sciences de la Terre Paris (iSTeP), 75005 Paris, France

3, CNRS, UMR 7193, Institut des Sciences de la Terre Paris (iSTeP), 75005 Paris, France

4, University Hassan II-Mohammedia, Faculty of Sciences Ben M'Sik, Casablanca, Morocco

5, National Institute of Marine Geology and Geo-ecology, 23-25 Dimitrie Onciul street, P.O. Box 34-51, 70318 Bucharest, Romania

6, CEFREM, Université de Perpignan, 52 Avenue Paul Alduy, 66860 Perpignan Cedex 9, France

7, Department of Earth Sciences, Brock University, 500 Glenridge Avenue, St. Catharines, Ontario L2S 3A1, Canada

8, Section of Earth and Environmental Sciences, University of Geneva, 13 rue des Maraîchers, 1205, Geneva, Switzerland

9, TOTAL, TG/ISS, CSTJF, Avenue Laribeau, 64018 Pau Cedex, France

10, TOTAL, PN/BTF, 2 place Jean Millier, 92400 La Défense, Paris, France

*Corresponding author: speranta.popescu@gmail.com

\section{Abstract}

We present a high-resolution analysis of planktonic foraminifers, calcareous nannofossils, ostracods, dinoflagellate cysts and pollen grains in four sequences from DSDP-ODP holes in the southwestern Mediterranean Alboran and Balearic basins (976B, 977A, 978A and 134B) encompassing the previously defined Messinian-Zanclean boundary.

The study focuses on (1) the marine reflooding, which closed the Messinian Salinity Crisis prior to the Zanclean GSSP; (2) the nature of the Lago Mare in the deep basins (indicated by Paratethyan dinoflagellate cysts), which appears to comprise several Paratethyan influxes without climatic control; and (3) the depositional context of the youngest Messinian evaporites which accumulated in a marine environment relatively close to the palaeoshoreline.

Isolation of the Aegean Basin during the paroxysmic second step of the crisis is considered to have stored Paratethyan waters, which may then have poured into the Mediterranean central basins after deposition of the evaporitic sequence.

Key-Words: High-resolution micropalaeontology, Messinian-Zanclean boundary, Marine reflooding, Lago Mare events, Deposition of the Upper Evaporitic Unit. 


\section{Introduction}

The southwestern Mediterranean Sea (Fig. 1) is a crucial target basin because it was (1) the site of water exchange between the Mediterranean Sea and Atlantic Ocean before the Messinian Salinity Crisis (MSC) (Krijgsman, 2002; Warny et al., 2003; and references therein), and (2) is ideally positioned to examine the marine reflooding that ended the MSC (Blanc, 2002; Garcia-Castellanos et al., 2009; Bache et al., 2012). It is therefore well suited to reconstruct events at the shift from the Messinian desiccation to the Zanclean deluge (Hsü et al., 1973). It is particularly useful for deciphering processes relating to the so-called "Lago Mare" biofacies, characterized by the occurrence of organisms of the former Paratethys (molluscs, ostracods, dinoflagellates; Gignoux, 1950; Ruggieri, 1962; Cita and Colombo, 1979; Bertini et al., 1995; Orszag-Sperber, 2006). For some authors, the Lago Mare biofacies marks the final stage of the MSC, and is isochronous wherever its geographic location in peripheral or central basins (Roveri et al., 2014a). For others, it represents three geographically and chronologically distinct episodes (Clauzon et al., 2005; Popescu et al., 2009; Do Couto et al., 2014), the first (LM 1) ending the first step (marginal) of the MSC in peripheral basins, the second (LM 2) ending the second step (paroxysmal) of the MSC in the central basins, and the third (LM 3) immediately following the final marine catastrophic reflooding (i.e., the $2^{\text {nd }}$ step of reflooding described by Bache et al. (2012)) recorded in both central and peripheral basins. The two steps of the MSC are those defined by Clauzon et al. (1996) (Fig. 2), which are largely accepted (CIESM, 2008).

Three ODP sites (Leg 161: Sites 976, 977, 978) have been drilled in the Alboran Sea (Fig. 1). They document the refilling of the Mediterranean Basin by oceanic waters despite the absence of Messinian evaporites. In addition, the easternmost DSDP Site 134 from the Balearic Basin (Leg 13; Fig. 1) displays the passage from central evaporites to Zanclean sediments, to which the Alboran holes need to be compared. We sampled at high resolution the ad hoc sedimentary interval in the four cored boreholes in order to perform biostratigraphic and palaeoenvironmental analyses based on planktonic foraminifers, calcareous nannoplankton, ostracods, dinoflagellate cysts, spores and pollen.

Many fundamental scientific questions are not yet resolved:

- were the central evaporites deposited in shallow water (Hsü et al., 1973; Bache et al., 2012, 2015) or deep water (Krijgsman et al., 1999; Roveri et al., 2014c)?

- was the Lago Mare a single event (Roveri et al., 2014a) or a cluster of three episodes (Do Couto et al., 2014)?

- does the significance of the Lago Mare biofacies differ between deep central basins and the peripheral basins?

- was the refilling by Atlantic waters sudden and massive (Hsü et al., 1973; Blanc, 2002; Garcia-Castellanos et al., 2009) or initially progressive and then rapid and violent when the Gibraltar sill collapsed - the two step reflooding of Bache et al. (2012)?

This work aims to clarify these aspects by generating new data on material that has not been revisited in more than sixteen years for Sites 976-978 (Iaccarino and Bossio, 1999; Serrano et al., 1999; Siesser and de Kaenel, 1999) and forty-two years for Site 134 (Cita, 1973; Ryan et al., 1973). Results and interpretations are presented for each site and compared with the previous data.

\section{Methods}

The following specific methods have been performed on fractions of the obtained clayey sediment:

- foraminifers and ostracods: 10-15 grams were disintegrated in a warm solution of sodium carbonate $\left(\mathrm{Na}_{2} \mathrm{CO}_{3}\right)$; residue was sieved at $50 \mu \mathrm{m}, 150 \mu \mathrm{m}$ and $250 \mu \mathrm{m}$, and all the material 
was analysed;

- calcareous nannoplankton: 2 grams were used to prepare smear slides for microscopic examination under bright light and polarized light at x1200 magnification;

- pollen grains and dinoflagellate cysts: acid treatments using $\mathrm{HCl}, \mathrm{HF}$, and $\mathrm{HCl}$ again on 10-15 grams followed by concentration in $\mathrm{ZnCl}_{2}$ (at density 2.0) and sieving at $10 \mu \mathrm{m}$; a $50 \mu \mathrm{l}$ volume of residue was mounted in glycerol and examined under a light microscope (magnification: x1000).

Biostratigraphic datums for planktonic foraminifers are based on Lourens et al. (2005) and Iaccarino et al. (2007), and those of calcareous nannofossils refer to Martini (1971), Perch-Nielsen (1985), and Raffi et al. (2006). Their respective ages are given by Lourens et al. (2005) and Raffi et al. (2006) with the distinction made between global oceanic ages and the Mediterranean ones (Fig. 2). Dinoflagellate cyst taxa are grouped according to their surface-water tolerance, nutritional strategy, and geographical provenance (Table 1) based on Warny and Wrenn (2002), Londeix et al. (2007), and Popescu et al. (2009) with modifications.

Planktonic foraminifers were counted and the percentage curves of the most significant species are shown. The coiling change of Neogloboquadrina acoastensis was calculated using the method of Iaccarino et al. (1999). Specimens of Globorotalia margaritae and Sphaeroidinellopsis were also counted because of their relevance in identifying the Messinian-Zanclean boundary, particularly the Sphaeroidinellopsis Acme-Zone, the age of which is labeled AB (acme base) and AT (acme top) in Figure 2. We also enumerated Globorotalia scitula with respect to coiling because Iaccarino et al. (1999) considered the common occurrence of dextral forms as representing "a delayed invasion event after the Pliocene flooding" just like that of Globorotalia margaritae.

We did not count calcareous nannofossils but focused instead on locating the lowest occurrence of Ceratolithus acutus and highest occurrence of Triquetrorhabdulus rugosus. Our analyses are based on the examination of more than fifty fields of view, recording a representative assemblage of the calcareous nannoflora. Di Stefano and Sturiale (2010) proposed a new species, Reticulofenestra zancleana, considered to be restricted to the earliest Zanclean and to characterize the MessinianZanclean boundary. Another species, Reticulofenestra cisnerosii, was previously proposed by Lancis and Flores (2007) to have the same potential. These species are not considered in recent international biostratigraphic charts (Anthonissen and Ogg, 2012; Zeeden et al., 2013), and were not recorded in the present study.

\section{ODP Site 976}

Hole $976 \mathrm{~B}\left(36^{\circ} 12^{\prime} 18.78^{\prime \prime} \mathrm{N}, 4^{\circ} 18^{\prime} 45.78^{\prime \prime} \mathrm{W}\right.$; water depth $1108 \mathrm{~m}$; Fig. 1) is the westernmost cored well in the Alboran Sea.

\subsection{Previous data}

In Hole 976B, the Messinian-Zanclean boundary was placed approximately within the interval $574.08-572.35 \mathrm{~m}$ below sea floor (bsf), mainly using (1) the lowest occurrence of Globorotalia margaritae and the highest occurrence of Globorotalia conomiozea (Zahn et al., 1996a; Serrano et al., 1999), and (2) the highest occurrence of Reticulofenestra rotaria (Siesser and de Kaenel, 1999) (Fig. 3). A hiatus was inferred at the level of the highest occurrence of $R$. rotaria, which is considered to have disappeared earlier, at about $6 \mathrm{Ma}$ according to Raffi et al. (2006). A gap in recovery occurs between 582.90 and 573.85 mbsf (Fig. 3).

\subsection{New data}

We studied 38 samples between 587.33 and 563.99 mbsf. Selected results are shown in Figure 3 and complete records in Supplementary data 1-4. Planktonic foraminifers and ostracods were 
searched throughout. The analysis of calcareous nannofossils was restricted to the lower samples up to the record of Ceratolithus acutus and C. rugosus which follow the post-MSC final catastrophic reflooding and mark the lower Zanclean, respectively: the interval covered is 587.33-584.01 mbsf. Dinoflagellate cysts were analysed in all samples. Only three samples yielded pollen grains, at $583.71,583.43$ and 573.56 mbsf.

\subsubsection{Biostratigraphy}

Planktonic foraminiferal distributions prima facie place the Messinian-Zanclean boundary at 572.88 mbsf, with the lowest frequent specimens of Sphaeroidinellopsis and Globorotalia margaritae (Fig. 3; Suppl. data 1) occurring consistently with the previous studies (Zahn et al., 1996a; Serrano et al., 1999; Siesser and de Kaenel, 1999), despite some rare occurrences of these species below (582.91-573.29 mbsf; Fig. 3; Suppl. data 1).

However, this interpretation is questioned by the lowest occurrence of the calcareous nannofossil Ceratolithus acutus at 585.22 mbsf which follows the post-MSC final catastrophic reflooding, as also supported by the lowest occurrence of C. rugosus at 584.02 mbsf (Fig. 3; Suppl. data 2). The corresponding ages, 5.345 and 5.12 Ma respectively (Fig. 2; Raffi et al., 2006), allow the Messinian-Zanclean boundary (5.332 Ma; Fig. 2) to be located between 585.22 and 584.02 mbsf. However, the highest occurrence of Triquetrorhabdulus rugosus (5.279 Ma; Fig. 2; Raffi et al., 2006) is also recorded at 585.22 mbsf (Fig. 3; Suppl. data 2). Hence, we propose placing the Messinian-Zanclean boundary at $585.22 \mathrm{mbsf}$. This proposal is supported by the evidence of large numbers of sinistral specimens of Neogloboquadrina acostaensis starting at this level (Fig. 3), consistent with the observations of Iaccarino et al. (1999) and Pierre et al. (2006). Additional support for this placement of the Messinian-Zanclean boundary at $585.22 \mathrm{mbsf}$ is the influx of dextral specimens of Globorotalia scitula at $583.14 \mathrm{mbsf}$ (Suppl. data 1). But the final catastrophic reflooding level is difficult to demonstrate a little below this level because it is impossible to know whether the lowest occurrence of Ceratolithus acutus at $585.22 \mathrm{mbsf}$ (Fig. 3) reflects its regional lowest occurrence because of its scarcity. In addition the proximity between the highest occurrence of Triquetrorhabdulus rugosus at $585.22 \mathrm{mbsf}$ and the C. acutus-C. rugosus cross-over between 584.34 and 584.01 mbsf suggests that the final catastrophic reflooding episode and the earliest Zanclean might correspond to a condensed sedimentary interval. As a consequence of this interpretation, the specimens of Globorotalia miotumida gr. recorded from 585.22 to $573.29 \mathrm{mbsf}$ must be considered reworked (Fig. 3; Suppl. data 1). With respect to this interpretation, the lowest occurrence of Globorotalia margaritae $(573.84 \mathrm{mbsf}$ ) should be placed at $5.08 \mathrm{Ma}$, whereas the high abundance of Sphaeroidinellopsis at $572.88 \mathrm{mbsf}$ would be above the Sphaeroidinellopsis Acme-Zone (ending at 5.21 Ma; Fig. 2). Similar isolated maxima in Sphaeroidinellopsis during the Zanclean have already been indicated by Spaak (1983).

The stratigraphic succession of marker microfossils observed in this hole is not unusual. The sedimentary interval 585.22-584.01 mbsf must be regarded as a condensed layer deposited just after the Gibraltar sill collapsed, a scenario not surprising given the greatly disturbed environment (Campillo et al., 1992; Blanc, 2002; Garcia-Castellanos et al., 2009; Bache et al., 2012). At that time, this area saw intensive current activity between the Mediterranean Sea and Atlantic Ocean that would have resulted in low rates of sediment deposition. We did not record Reticulofenestra rotaria in the studied samples (Suppl. data 2), suggesting its reworked origin in the aforementioned study (Siesser and de Kaenel, 1999).

The open-ended question regards the age of the sediments from 587.33 to $586.15 \mathrm{mbsf}$, where Globorotalia conomiozea is abundant (Suppl. data 1). This species is considered to have disappeared at about 6.52 Ma (Lourens et al., 2005; Fig. 2). Its occurrence in such abundance leads us to believe that it is not reworked and that a long hiatus may separate deposits of the final catastrophic reflooding from those below. A long hiatus is indeed highly likely within the palaeochannel evidenced by Campillo et al. (1992) where Hole 976B was cored, most likely the result of 
the Gibraltar collapse and extensive erosion by the massive floods of waters and associated suspended sediments (Garcia-Castellanos et al., 2009; Estrada et al., 2011). As a consequence, we suggest that the final catastrophic reflooding should be placed at 585.22 mbsf coinciding with the Messinian-Zanclean boundary or a slightly below (possibly $585.82 \mathrm{mbsf}$ as supported by dinoflagellate cysts - see below; Fig. 3). There is no significant lithological change at this level (Zahn et al., 1996a, 1996b).

\subsubsection{Palaeoenvironments}

Few but well-preserved ostracod shells were recorded. They consist of fully marine species (Bosquetina carinella, Bairdia sp., Krithe aequabilis, Argilloecia acuminata, Parakrithe sp.). Despite the low abundance and diversity, these ostracods are not considered reworked owing to their excellent preservation and indication of fully marine conditions.

Marine dinoflagellate cysts are abundant and have been subdivided into four groups (Fig. 3; Suppl. data 3):

- marine stenohaline (oceanic-outer platform) taxa;

- marine euryhaline (inner platform-coastal) taxa;

- marine heterotrophic (inner platform-coastal) taxa;

- brackish Paratethyan taxa.

Freshwater algae are also plotted.

Based on the mean relative abundance of marine species, we propose:

- a proximal position for the site with respect to the shoreline, as indicated by the dominance of inner platform-coastal taxa that reached a mean relative abundance of about $65 \%$ for the interval 587.33-582.91 mbsf;

- an initial rise in sea level at $585.82 \mathrm{mbsf}$, as documented by a maximum development of marine species (94\%) that may reflect the final catastrophic reflooding of the Mediterranean at $5.46 \mathrm{Ma}$;

- a re-establishment of water masses and the onset of modern exchanges via currents through the Gibraltar Strait above the level at 573.84 mbsf, as indicated by the almost constant ratio of marine stenohaline and euryhaline taxa.

The brackish Paratethyan dinoflagellate taxa, represented by Galeacysta etrusca and Spiniferites bentorii oblongus (Fig. 3; Suppl. data 3), were found only in the sample at 586.77 mbsf. This Lago Mare signal occurs too low stratigraphically with respect to the lowest occurrence of Ceratolithus acutus to be the LM 2, and even the LM 1 if we consider the above-supposed hiatus and the age of the disappearance of Globorotalia conomiozea at ca. $6.52 \mathrm{Ma}$ (Fig. 2; Lourens et al., 2005). Could this represent an earlier influx of Paratethyan species during a pre-MSC exchange episode with the Mediterranean (Popescu et al., 2009) (Fig. 2)? Paratethyan molluscs predating 6.10 Ma (Garcés et al., 1998) have been recorded at Crevillente, southern Spain (Archambault-Guézou et al., 1979; Fig. 1). In any case, this Lago Mare episode corresponds to an influx of Paratethyan surface waters into the Mediterranean Basin filled by marine waters. Marine heterotrophic taxa are almost constant (mean relative abundance at 4.6\%), except for two intervals, respectively just after the final catastrophic reflooding where these taxa increase to $15 \%$ at $584.97 \mathrm{mbsf}$ and $23 \%$ at $571.93 \mathrm{mbsf}$.

Modern pollen records from Alboran Sea surface sediments have confirmed their consistency with the present-day vegetation, illustrating the ability of marine pollen to record vegetation on shorelines of a narrow sea (Suc et al., 1999). The pollen flora from Hole 976B (Fig. 3; Suppl. data 4) is dominated by bisaccate pollen (mainly Pinus and Cathaya), in agreement with the postreflooding location of the samples, as these pollen types are advantaged by water and air transport. Herbs are prevalent, including some steppe subdesertic elements (Hippophae rhamnoides, Chamaerops humilis, Lygeum). Halophytes (Amaranthaceae-Chenopodiaceae, Caryophyllaceae, Plumbaginaceae, Ephedra, and the mangrove element Avicennia) are frequent, reflecting shoreline vegetation. Mediterranean xerophytes are present (Nerium, Olea, Phillyrea, Pistacia, Quercus ilex- 
type). Subtropical elements are present, but warm-temperate trees (mainly deciduous Quercus) dominate. Mountains of the hinterland are illustrated by altitudinal trees (Cathaya, Cedrus, Abies and Picea). This pollen flora is very similar to that of the Lower Zanclean of the Andalucia G1 well (Fig. 1) which indicates a mean annual temperature of $23^{\circ} \mathrm{C}$ and annual precipitation of $380 \mathrm{~mm}$ (Feddi et al., 2011).

\section{ODP Site 977}

Hole 977A was drilled in the deepest part of the eastern Alboran Sea $\left(36^{\circ} 01^{\prime} 54.42^{\prime} \mathrm{N}\right.$, 157'19.14”'W; water depth 1984 m; Fig. 1).

\subsection{Previous data}

In Hole 977A, the Messinian-Zanclean boundary was placed at $532.88 \mathrm{mbsf}$, where the seismic reflector " $\mathrm{M}$ " is located (with difficulty because of scarce markers), based on the occurrence of Globorotalia margaritae at 531.27 mbsf (Zahn et al., 1996c) (Fig. 4). No markers were identified among the calcareous nannofossils in the lowermost interval 532.88-531 mbsf (Siesser and de Kaenel, 1999). The underlying sandstone (top at $540.70 \mathrm{mbsf}$ ) was referred to a strong erosional event related to the violent marine reflooding of the Mediterranean Basin (Zahn et al., 1996c).

\subsection{New data}

Our study concerns six samples, distributed between 532.88 and $531 \mathrm{mbsf}$. Selected results are shown in Figure 4 and complete records in Supplementary data 5-7. Planktonic foraminifers, calcareous nannofossils and dinoflagellate cysts are recorded in all samples. Dinoflagellate cysts have been analysed in each one. No ostracods were recorded. Pollen grains were found to be very rare, preventing significant analysis.

\subsubsection{Biostratigraphy}

All samples contain Globorotalia margaritae, three of them $G$. puncticulata including the lowermost ones, and two of them Ceratolithus rugosus including the lowermost one (Fig. 4; Suppl. data 5). This association indicates a late Zanclean age for the lowermost clays recovered in Hole 977A, ranging between 4.52 Ma (lowest occurrence of G. puncticulata) and $3.81 \mathrm{Ma}$ (highest occurrence of G. margaritae) (Lourens et al., 2005; Fig. 4). We note the weak dominance of sinistral specimens of Neogloboquadrina acostaensis (Fig. 4). According to these biostratigraphic data, we question the labeling of the "M" reflector and proposed relationship of the sandstone topping at $540.70 \mathrm{mbsf}$ with the marine reflooding, unless a more condensed layer than that presumed for Hole 976B was not recovered at the base of the clays of Hole 977A.

\subsubsection{Palaeoenvironments}

The dinoflagellate cyst assemblage reflects open ocean conditions for the studied interval, based on the dominance of Impagidinium patulum (24-61\% of the total dinoflagellate cyst assemblages). No brackish Paratethyan species were recorded.

\section{ODP Site 978}

Hole 978A (36²' $52.02^{\prime \prime}$ N, 203'25.44'W; water depth 1929.40 m; Fig. 1) was drilled in the same part of the Alboran Sea as Hole 977A but north of it. 


\subsection{Previous data}

The Messinian-Zanclean boundary was placed at $607.28 \mathrm{mbsf}$ (Fig. 5), despite the absence of unequivocal markers both among planktonic foraminifers and calcareous nannofossils (Zahn et al., 1996d; Siesser and de Kaenel, 1999). For Iaccarino and Bossio (1999), this placement was reinforced by their record of the calcareous nannofossil Reticulofenestra rotaria below $630 \mathrm{mbsf}$, which is considered to have disappeared at ca. $6 \mathrm{Ma}$ (Raffi et al., 2006; Fig. 2). However, Siesser and de Kaenel (1999) indicated this species as being very scarce for the same sampled interval. The superjacent normal palaeomagnetic interval (from about 610-602 to $570 \mathrm{mbsf}$ ) was consistently ascribed to Chron C3n.4n (Zahn et al., 1996d; Fig. 2). The unrecovered underlying conglomeratic layer between 630.60 and $620.90 \mathrm{mbsf}$ was considered as corresponding to the "M" reflector marking the Messinian unconformity (Comas et al., 1992; Zahn et al., 1996d).

\subsection{New data}

Our study is based on 26 samples between 635.30 and 601.80 mbsf. Selected results are shown in Figure 5 and complete records in Supplementary data 8-11. Planktonic foraminifers and ostracods have been searched in all of them. Analysis of calcareous nannofossils was restricted to some samples within the lower part of the studied interval up to the record of Ceratolithus acutus and $C$. rugosus which follows the final catastrophic reflooding and marks the lower Zanclean, respectively: the interval covered is 634.17-603.29 mbsf. Dinoflagellate cysts were recorded in 23 of the samples, from 635.30 to $601.80 \mathrm{mbsf}$. Pollen grains were recorded in 15 samples from two intervals: $635.30-630.98$ and 605.74-605.29 mbsf.

\subsubsection{Biostratigraphy}

The lowest occurrence of Globorotalia margaritae was recorded at 607.19 mbsf, just below the lowest occurrence of Sphaeroidinellopsis, recorded at $606.55 \mathrm{mbsf}$ (Fig. 5; Suppl. data 8). Contrary to previous studies, these taxa were recorded frequently within the studied interval. This observation is in agreement with the above-mentioned interpretation of the Messinian-Zanclean boundary at 607.28 mbsf (Fig. 5). However, the calcareous nannofossils Ceratolithus acutus and C. rugosus were consistently recorded at 632.45 and $605.74 \mathrm{mbsf}$, respectively, also consistently with the occurrence of Discoaster quinqueramus at $634.17 \mathrm{mbsf}$ (Fig. 5). Accordingly, and with respect to accepted biostratigraphic datums (Fig. 2), we (1) envision the final catastrophic reflooding as occurring at ca. 633.66 mbsf just above a gravel layer, and (2) lower the Messinian-Zanclean boundary to ca. $630.80 \mathrm{mbsf}$ (Fig. 5). This new ascription fits with the normal palaeomagnetic episode possibly starting at $610 \mathrm{mbsf}$ referred to Chron C3n.4n and with the almost continuous dextral coiling of Neogloboquadrina acostaensis observed from 611.32 mbsf (Fig. 5; Suppl. data 8). Globorotalia scitula was very rare and could not be used for biostratigraphic interpretation (Suppl. data 8). As a consequence, our specimens of Globorotalia miotumida gr. recorded at $611.32 \mathrm{mbsf}$ and possibly at 630.98 mbsf must be considered reworked, as also those of Reticulofenestra rotaria found by Iaccarino and Bossio (1999) between 633 and 630 mbsf (Fig. 5). In addition, we agree with the relationship of the conglomeratic layer $(630.60-620.90 \mathrm{mbs})$ with the " $\mathrm{M}$ " reflector. The underlying gravel level (634.00-633.50 mbsf; Fig. 5) may thus correlate with the final catastrophic reflooding at $5.46 \mathrm{Ma}$.

\subsubsection{Palaeoenvironments}

The ostracod recovery is very poor in the analysed samples. However the recorded species (Krithe aequabilis, Argilloecia acuminata, Henryhowella asperrima) indicate a bathyal marine environment.

Marine eurhyaline dinoflagellate cysts prevail from the base of the studied interval up to 632 mbsf, above which marine stenohaline taxa are dominant (Fig. 5; Suppl. data 10). We note that this turnover, observed between 633.66 and $633.06 \mathrm{mbsf}$, occurs approximately at the level where we 
located the final catastrophic reflooding (634.00-633.50 mbsf). This hole would be the first to document the continuous rise in sea level, which followed the final catastrophic reflooding. Two samples yielded brackish Paratethyan dinoflagellate cysts: 635.30 mbsf (Galeacysta etrusca and Spiniferites tihanyensis), and $601.80 \mathrm{mbsf}$ (Galeacysta etrusca, S. bentorii oblongus, S. bentorii pannonicus and Spiniferites spp.) (Fig. 5; Suppl. data 10). Their separation and the resulting biostratigraphic implications lead us to consider two different Lago Mare events (Fig. 5). The youngest of these is definitely the LM 3 episode because it is located significantly above the Messinian-Zanclean boundary (Fig. 2). This event occurred in a fully oceanic realm (Fig. 5), supporting the hypothesis of a Paratethys-Mediterranean connection at high sea level (Clauzon et al., 2005; Popescu et al., 2009; Do Couto et al., 2014). The oldest Lago Mare event is located a short distance below the final catastrophic reflooding level (Fig. 5). However, in the absence of central evaporites in the Alboran Basin, we cannot argue whether LM 2 or LM 1 is recorded here (Fig. 2). It occurred in a shallow marine environment, which could in fact correspond to either episode. Such a depositional set up was described by Iaccarino and Bossio (1999), who documented a thick Lago Mare biofacies from ca. 693 to $630 \mathrm{mbsf}$ based on the occurrence of small-sized planktonic foraminifers and brackish foraminifers (Ammonia tepida, Protelphidium granosum) with Paratethyan ostracods found below $650 \mathrm{mbsf}$. But taking into account the high potential for brackish species to survive in coastal lagoons, Do Couto et al. (2014) showed that only the layers with Paratethyan dinoflagellate cysts can be reliably regarded as the signal of the entrance of Paratethyan surface waters into the Mediterranean Basin, whether it was desiccated (peak of the MSC) or not (before the peak of the MSC or after the reflooding).

The pollen flora from Hole 978A (Fig. 5; Suppl. data 11) is dominated by bisaccate pollen grains (mainly Pinus), particularly after the final catastrophic reflooding located at ca. 634.00-633.50 mbsf, and in the earliest Zanclean consistent with maximum flooding. Herbs are prevalent, including some steppe subdesertic elements (Calligonum, Chamaerops humilis, Lygeum). Halophytes are frequent, reflecting vegetation from the shoreline. Few tropical and some subtropical elements are present but warm-temperate trees (mainly deciduous Quercus) dominate the arboreal pollen. Mountains of the hinterland are reflected by altitudinal trees (Cathaya, Cedrus, Abies and Picea). This pollen flora is very similar to that of Hole 987B (Fig. 3; Suppl. data 4) and of the Lower Zanclean of the Andalucia G1 well (see above).

\section{DSDP Site 134}

Hole 134B (39¹1'42.00'N, 7¹8'15.00”W; water depth 2864 m; Fig. 1), cored in the Balearic Basin, is one of the few deep sea wells to have penetrated the Upper Evaporitic Unit in a central basin (i.e., UU of Lofi et al., 2011) and includes halite layers (Fig. 6). Dolomitic marls at 360 mbsf have yielded allochtonous hydrocarbons (Ryan et al., 1973).

\subsection{Previous data}

In this hole, the Messinian-Zanclean boundary was placed at $324.30 \mathrm{mbsf}$ at the lowest cooccurrence of the planktonic foraminifers Sphaeroidinellopsis seminulina and Globorotalia margaritae by Cita (1973) who identified the G. margaritae specimens as belonging to the subspecies G. margaritae margaritae within the G. margaritae lineage. Because of the coeval lowest occurrence of G. margaritae margaritae and Sphaeroidinellopsis, Cita (1973) suggested that a sedimentary gap affects the base of the Zanclean Series at Site 134, unlike the Tyrrhenian Site 132 where the Zanclean Series starts with Sphaeroidinellopsis alone (Sphaeroidinellopsis Acme-Zone). This same conclusion was accepted based on the calcareous nannofossil record, despite an absence of biostratigraphic markers except for Ceratolithus (=Amaurolithus) tricorniculatus, a species crossing the Messinian-Zanclean boundary (Bukry, 1973; Gartner, 1973; Ryan et al., 1973). The 
"M" reflector was reasonably located at the top of the Upper Unit, i.e. at 344.90 mbsf (Ryan et al., 1973).

A single sample at 324.23 mbsf yielded ostracods. The assemblage, comprising Krithe sp., Henryhowella sp. and Agrenocythere pliocenica, is marine and characteristic of deep waters (Benson, 1973).

\subsection{New data}

Our study is based on 28 samples between 361.90 and 321.76 mbsf. The lower 13 samples belong to the Upper Unit, the upper 15 to the overlying clays (Fig. 6). Selected results are shown in Figure 6 and complete records in Supplementary data 12-15. Planktonic foraminifers, calcareous nannofossils, dinoflagellate cysts, and pollen grains have been searched in all samples with mixed success: 21 productive samples for planktonic foraminifers, 20 for calcareous nannofossils, 21 for dinoflagellate cysts, and 16 for pollen grains.

\subsubsection{Biostratigraphy}

From 324.35 to $321.76 \mathrm{mbsf}$, the planktonic foraminiferal fauna (Fig. 6; Suppl. data 12) is characterized by the continuous abundance of Globorotalia margaritae and almost continuous occurrence of Sphaeroidinellopsis. Below, assemblages are poor and composed of dwarf specimens, except in the sample at 361.52 mbsf which includes Globorotalia miotumida gr. This places the Messinian-Zanclean boundary at almost the same level as Cita (1973) for this hole (Fig. 6). However, we did not record the peaks of sinistral individuals of Neogloboquadrina acostaensis, which is dominated by dextral forms through the interval 324.35-321.76 mbsf (Fig. 6; Suppl. data 12). This suggests that the Messinian-Zanclean boundary should be located within the underlying unrecovered interval (326.00-324.80 mbsf). Globorotalia scitula was rare but dextral forms were prevalent from $324.25 \mathrm{mbsf}$ (Suppl. data 12).

Calcareous nannofossil assemblages are rich from 326.18 to 321.76 mbsf (Fig. 6; Suppl. data 13). They contain Ceratolithus acutus with Triquetrorhabdulus rugosus at $323.09 \mathrm{mbsf}$, and only $C$. acutus at 322.05 mbsf. Triquetrorhabdulus rugosus is also present at $323.54 \mathrm{mbsf}$. Considering the planktonic foraminiferal record, Discoaster quinqueramus and D. berggrenii are regarded as reworked from $324.35 \mathrm{mbsf}$ to the top of the studied interval, and only in place at $326.18 \mathrm{mbsf}$. Because we focused on the top of the Upper Unit and the immediately overlying sediments, Nicklithus amplificus, recorded in several samples from 326.18 mbsf to the top of the studied interval, is considered as reworked because it apparently disappeared at ca. 5.939 Ma (Raffi et al., 2006; Fig. 2).

Regarding the above limits on the reliability of Discoaster quinqueramus-D. berggrenii in Hole 134B, the succession D. quinqueramus-D. berggrenii (326.18 mbsf), then Triquetrorhabdulus rugosus (323.54 mbsf), then T. rugosus plus Ceratolithus acutus (323.09 mbsf), and finally $C$. acutus alone (322.05 mbsf) fits with the accepted sequence of calcareous nannofossil datums (Fig. 2). It is, however, difficult to accept that the lowest record of Ceratolithus acutus at 323.09 mbsf actually corresponds to its lowest regional occurrence, all the more because it occurs at the same level as the highest record of Triquetrorhabdulus rugosus, characterized by a planktonic foraminifer assemblage with abundant Globorotalia margaritae, Sphaeroidinellopsis and dextral Neogloboquadrina acostaensis (Fig. 6; Suppl. data 12). Although early records of Sphaeroidinellopsis and G. margaritae have been observed in the Sorbas Basin (Clauzon et al., 2015), we prefer to place the Messinian-Zanclean boundary within the underlying unrecovered interval, i.e. at 325.50 mbsf (Fig. 6), than at the lowest record of Ceratolithus acutus.

\subsubsection{Palaeoenvironments}

The dinoflagellate cyst assemblages are continuously marine (mostly comprising Impagidinium spp., Spiniferites spp., Operculodinium spp., etc.) (Fig. 6; Suppl. data 14). Eurhyaline species 
significantly dominate in the uppermost evaporitic layers $(361.12,360.12,326.18,326.08 \mathrm{mbsf})$. Specimens of stenohaline species become more abundant above $324.35 \mathrm{mbsf}$ while the eurhyaline specimens significantly decrease within the interval 326.18-326.08 mbsf, consistently with the proposed location of the Messinian-Zanclean boundary at $325.50 \mathrm{mbsf}$ (Fig. 6). Dinoflagellate cyst assemblages from the Upper Unit or just above (interval 361.75-326.08 mbsf) document marine conditions, even though the samples are poor or devoid of planktonic foraminifers and calcareous nannofossils. This observation agrees with the transgressive status usually conferred upon the Upper Unit of the central Mediterranean basins (Gorini et al., 2005; Bache et al., 2009; Lofi et al., 2011), which was probably deposited beneath a significant water depth. Two isolated pairs of samples between two isolated samples yielded brackish Paratethyan dinoflagellate cysts: 361.12 mbsf (Impagidinium caspienense, Millioudodinium sp.), 326.18-326.08 mbsf (Galeacysta etrusca, Spiniferites cruciformis, S. validus, Spiniferites spp., Pyxidinopsis psilata, Impagidinium globosum, Pontiadinium spp.), 324.35-324.25 mbsf (abundant Galeacysta etrusca, Spiniferites cruciformis, $S$. bentorii oblongus, S. validus, abundant Spiniferites spp., Pyxidinopsis psilata, Millioudodinium punctatum, Millioudodinium spp., Pontiadinium spp.), and $323.31 \mathrm{mbsf}$ (Impagidinium caspienense) (Fig. 6; Suppl. data 14). Based on their position relative to the Upper Unit and according to our biostratigraphic interpretation, we consider these influxes of Paratethyan dinoflagellate cysts to represent two successive Lago Mare events (Fig. 6). The older of these (sample 361.12 mbsf plus interval 326.18-326.08 mbsf) is located in the topmost Upper Unit or immediately above it: we assign it to the LM 2 episode (Fig. 2). The younger event (interval 324.35-324.25 mbsf plus sample $323.31 \mathrm{mbsf}$ ), characterized by a greater diversity, follows the final catastrophic reflooding: this is the LM 3 episode. It occurred in an oceanic context (Fig. 6), supporting the hypothesis of a Paratethys-Mediterranean connection at high sea level (Clauzon et al., 2005; Popescu et al., 2009; Do Couto et al., 2014).

As with the Alboran Sea (see Subsection 3.2.2), a modern (surface sediment) pollen record off southeastern Sardinia shows the reliability of this kind of pollen record in reflecting the present-day vegetation, and supports the use of fossil pollen in such marine deposits to reconstruct past vegetation (Suc et al., 1999). Data are presented in Figure 6 and Supplementary data 15. Pinus and Cathaya (bisaccate pollen grains, concentrated by air and water transport) dominate pollen assemblages in the sample at $360.12 \mathrm{mbsf}$ and through $324.35-321.76 \mathrm{mbsf}$, denoting a distal marine location for the site and probably high sea level. The lower part of this pollen record (361.52-326.08 mbsf) is the only record, except for poor pollen floras from the Tyrrhenian DSDP Sites 132 and 374 (Bertolani Marchetti and Cita, 1975; Bertolani Marchetti and Accorsi, 1978), to provide robust information on vegetation during the deposition of the Messinian central evaporites. This palaeovegetation covered Sardinia and emergent areas to the west during the Mediterranean desiccation (peak of the MSC) and was restricted to Sardinia after the final catastrophic reflooding. Halophyte pollen grains (Amaranthaceae-Chenopodiaceae, Caryophyllaceae, Ephedra, Tamarix) are abundant, particularly in samples from evaporitic deposits (361.52 and $360.12 \mathrm{mbsf}$ ), reflecting the extent of herbaceous coastal environments (for a modern analogue, see Cambon et al., 1997). To complete the littoral landscape, we emphasize the widespread development of open vegetation including steppe (Artemisia) and subdesertic (Lygeum) plants and Mediterranean xerophytes (Olea, Phillyrea, Quercus ilex-type). Tropical elements are very rare, and both subtropical and warmtemperate taxa have low frequencies except for deciduous Quercus. Abundant pollen of Cathaya, Tsuga, Cedrus, Abies and Picea attests to the presence of high relief in Sardinia.

\section{Discussion}

Previous studies have investigated the Messinian-Zanclean boundary at high-resolution in the deep Mediterranean boreholes (Castradori, 1998; Spezzaferri et al., 1998; Iaccarino and Bossio, 
1999; Iaccarino et al., 1999), focusing on foraminifers, ostracods, and in some cases calcareous nannofossils. Our study is the first to integrate marine and continental proxies. Figure 7 summarizes our chronostratigraphic interpretation of the studied sections from ODP holes 976B, 977A, 978A and DSDP Hole 134B. Based on our high-resolution multi-proxy analyses of the relevant intervals, new proposals and refinements arise for the position of the Messinian-Zanclean boundary, and new perspectives are presented for the relationship with the seismic reflector " $\mathrm{M}$ " and location of the final catastrophic reflooding, and particularly the significance of the Lago Mare episodes. Finally, such analyses on Site 134 enable us to progress the debate on the environmental conditions of the Messinian evaporites in the central Mediterranean basins.

\subsection{The Messinian - Zanclean boundary}

We re-interpret the position of the Messinian-Zanclean boundary using both planktonic foraminifers and calcareous nannofossils, taking into account the newly documented older age of the final catastrophic marine reflooding of the Mediterranean Basin (Cavazza and DeCelles, 1998; Cornée et al., 2006; Bache et al., 2012). In doing so, we note that dinoflagellate cysts also provide decisive information.

For Hole 976B, we propose lowering the position of the Messinian-Zanclean boundary by about 11-13 $\mathrm{m}$, the level of the final catastrophic reflooding being difficult to distinguish at around 585.22 mbsf (Fig. 7). Hole 977A is thus released from the issue of locating the Messinian-Zanclean boundary (Fig. 7). Our results on Hole 978A allow us to lower the Messinian-Zanclean boundary by ca. 23-24 $\mathrm{m}$ and recognize the catastrophic reflooding $2.70-3.20 \mathrm{~m}$ below this boundary (Fig. 7). In Hole 134B, the Messinian-Zanclean boundary was lowered by $1.20 \mathrm{~m}$, without distinguishing the catastrophic reflooding (Fig. 7).

In the Alboran Sea, where Messinian evaporites are absent, a hiatus may separate the reflooding layer from the underlying sediments, as at holes 976B and 978A. This hiatus might be marked by a clastic bed, as in Hole 977A. Just above the reflooding layer, an interval of condensed sedimentation cannot be excluded, as in Hole 976B, and perhaps at the extreme base of the Zanclean deposits in Hole 977A. This study shows that the planktonic foraminifers Sphaeroidinellopsis and Globorotalia margaritae, which are commonly used for defining this boundary, must be used with caution. Contrary to the opinion of Di Stefano and Sturiale (2010), the calcareous nannofossil Ceratolithus acutus is frequent enough when searched in a large number of samples and must be regarded as the most reliable marker for identifying the final catastrophic reflooding of the Mediterranean (Castradori, 1998). Because it was defined in the Mediterranean after a desiccation phase, the Zanclean Global Boundary Stratotype Section and Point (GSSP) should be relocated to a continuous Atlantic sedimentary sequence (Benson and Hodell, 1994).

\subsection{Correlation of DSDP-ODP holes and seismic profiles}

Correlation between seismic profiles and the cored successions have mostly resulted in placing seismic reflector " $\mathrm{M}$ " with the proposed Messinian-Zanclean boundary at each drill site (Hole 134B: Ryan et al., 1973; holes 976, 977, 978: Zahn et al., 1996a, c, d). Two distinct contexts characterize the Balearic Basin and the Alboran Sea: in the former, the top of the Upper Evaporitic Unit (UU) obviously constitutes a relevant candidate for the reference horizon "M" (Ryan et al., 1973); in the latter, the channel resulting from the collapse of the Gibraltar sill is a clear morphological feature although often devoid of a lithological break (Estrada et al., 2011). The distinction between the major event that was the final catastrophic marine reflooding of the Mediterranean Basin and the conventional (uneventful) Messinian-Zanclean boundary (Cavazza and DeCelles, 1998; Cornée et al., 2006; Bache et al., 2012) leads us to discuss and in some cases question the position (and the meaning) of the "M" reflector within each cored series.

Hole $976 \mathrm{~B}$ was identified as occurring on the northern edge of the aforementioned channel by Estrada et al. (2011) who correlated the discontinuity labeled as the " $\mathrm{M}$ " reflector in their figure 5b 
with the previously proposed Messinian-Zanclean boundary (574.08-572.35 mbsf). These authors interpreted a thin sedimentary body immediately underlying this horizon as "Messinian remnants". In this profile, we lower the northernmost course of reflector " $M$ " at the base of this body in order to fit with the base of Zanclean at $585.22 \mathrm{mbsf}$ and, probably, the final catastrophic reflooding (Fig. 7). In Hole 977A, the unchanged "M" reflector with respect to Zahn et al. (1996c) would be younger than the basal Zanclean, unless a condensed layer exists between 532.88 and 532.75 mbsf (Fig. 7). In the first option, the importance of this horizon should be moderated. However, there is the possibility of a condensed layer marking the reflooding above reflector " $\mathrm{M}$ " according to the line shown by Estrada et al. (2011) in their figure 7a on which Site 977 is projected. It seems unlikely that this matter will be resolved with regard to the remaining available ODP material. Hole 978A was cored within the above-mentioned channel (Estrada et al., 2011). Our 26-m lowering of the level where the "M" horizon crosses the section (Fig. 7) appears conceivable with the seismic line shown by these authors in their figure $7 \mathrm{~b}$ where Site 978 is projected. We have not changed the correlation of the Hole 134B cored sequence with the seismic horizon "M" at 344.90 mbsf (Ryan et al., 1973; Sage et al., 2005; Fig. 7).

\subsection{Lago Mare events at the regional scale}

High-resolution analyses performed on holes 976B, 978A and 134B have revealed evidence of several influxes of Paratethyan dinoflagellate cysts into the deep Mediterranean central basins (i.e., the Lago Mare or LM episodes; Fig. 7). Biostratigraphy allows those preceding the final catastrophic reflooding to be distinguished from those following it, and more precisely to assign them to the three Lago Mare episodes as proposed by Clauzon et al. (2005), Popescu et al. (2009) and Do Couto et al. (2014), and possibly to an older one in Hole 976B. The first episode (LM 1) ends the first step of the MSC in peripheral basins, the second (LM 2) ends the second step of the MSC in the central basins, and the third (LM 3) immediately follows the final catastrophic marine reflooding. It was noted by the above authors that the record of Paratethyan dinoflagellate cysts reliably indicates the influx of surface waters from the Paratethys. Such influxes may then have extended over time as well as in space in coastal lagoons favorable to the development of the accompanying ostracods (Cyprideis group mainly) and molluscs (Dreissenids and Limnocardiids). Accordingly, the traditional view that recognizes just one Lago Mare event (Roveri et al., 2014a) should be abandoned.

In this study, the oldest Lago Mare episode is recorded in Hole 976B: it belongs a priori to LM 1 or perhaps to an older episode as recorded at Crevillente (Fig. 1) prior to 6.10 Ma (see Section 3.2.2). The lowermost Paratethyan influx recorded in Hole 978A would belong to LM 1 or LM 2, or maybe to both episodes as they could be juxtaposed with regard to the $65-\mathrm{m}$ thick brackish environment evidenced by Iaccarino and Bossio (1999). The two lowermost Paratethyan influxes evidenced at Site 134 are attributed to LM 2 because they are linked to the Upper Evaporitic Unit. Lastly, the uppermost Paratethyan influxes recorded in holes 978A and 134B belong to episode LM 3. These successive episodes from the Alboran and Balearic basins are shown in Figure 8 in comparison with the evidence based on ostracods and molluscs.

Comparisons can be made with exposed sections on land that successively or simultaneously display the various types of Lago Mare biofacies (dinoflagellate cysts and/or ostracods and molluscs). At Eraclea Minoa in southern Sicily, LM 1 and LM 3 have been defined (Popescu et al., 2009; Bache et al., 2012) subsequent to an initial dinoflagellate influx recorded beneath the highest gypsum bed of the Sicilian Upper Evaporites (Londeix et al., 2007; Fig. 8). There (Fig. 9), LM 1 corresponds to the Lago Mare Unit (Cita and Colombo, 1979), which shows two beds with dreissenids (Fig. 9C; Popescu et al., 2009) but is devoid of Paratethyan dinoflagellate cysts (Londeix et al., 2007). Discordantly, the overlying Arenazzolo Unit yielded Paratethyan dinoflagellate cysts only in its lower part (Fig. 9). Bache et al. (2012) showed that these stratigraphic units are separated by an unconformity, i.e. a sedimentary gap corresponding to the 
peak of the MSC that we call the Messinian Discontinuity (Fig. 9B; see also: Melinte-Dobrinescu et al., 2009). When erosional, this contact expresses the marine reflooding that terminates the MSC (Fig. 9A).

In southeastern Spain (Fig. 1), Lago Mare episodes have been identified before and after the peak of the MSC (Fig. 8):

- at San Miguel de Salinas (Bajo Segura Basin), such an episode predates the "end-Messinian unconformity" of Soria et al. (2008) that we refer to the Messinian Erosional Surface; this is the LM 1;

- at Cuevas del Almanzora, in the central part of the Vera Basin, LM 1 (Cita et al., 1980) is overlain by the Messinian Discontinuity (Fig. 10B) which is marked by a thin erosional conglomerate (Fig. 10C; Bernet Rollande et al., 1979; Fortuin et al., 1995); otherwise, the Messinian subaerial erosion is well-marked at the periphery of the basin such as at Garrapancho (Fortuin et al., 1995; Fig. 10A);

- near Málaga, LM 3 has been identified within the Gilbert-type fan delta overlying the Messinian Erosional Surface (Do Couto et al., 2014; Fig. 10D).

In the Crotone Basin, Calabria, the late Messinian erosional phase (relative to the Mediterranean Sea drawdown) is sandwiched between two Lago Mare layers (Zecchin et al., 2013) that we refer to episodes LM 1 and LM 3. We conclude that such a relationship between Lago Mare events 1 and 3 and the Messinian Erosional Surface or the Messinian Discontinuity is relatively common (Fig. 8).

At the Mediterranean periphery, many of the Lago Mare deposits reveal marine conditions, very littoral for LM 1 and more marine for LM 3 (Popescu et al., 2009). Such a marginal context and the coeval occurrence of marine (Mediterranean) microfossils in the Pannonian and/or Dacic and Euxinian basins led to the conception of high sea-level exchanges between the Mediterranean and Paratethys just before and just after the paroxysm of the MSC (Clauzon et al., 2005; Popescu et al., 2009; Bache et al., 2012; Suc et al., 2015). This concept is supported by fossil fish distributions (Carnevale et al., 2006a, b). All the influxes of Paratethyan dinoflagellate cysts identified in holes 976B, 978A and 134B occurred in a marine context, probably in more coastal conditions for LM 1 and LM 2, and more distal conditions for LM 3. These lines of evidence from central basins fit with the interpretation based on data from the peripheral sites. Some peripheral Lago Mare deposits reflect a lagoon environment, such as those known at Sorbas and Níjar (Do Couto et al., 2014). It is proposed that some elements of the Lago Mare assemblages (molluscs, ostracods) may have survived the influx episode by colonizing lagoons back from the shoreline where they may have persisted for some time (Do Couto et al., 2014). This assumption is expressed in Figure 8 as the expansion of these Paratethyan taxa in space and/or time.

The LM 2 episode is documented only in long boreholes from the Mediterranean central basins. Its understanding remains elusive. Holes 978A and 134B show that there is no significant increase in freshwater algae along with the influx of Paratethyan dinoflagellate cysts. This suggests discarding as a source the input of rivers from the drainage of African mega-lakes as proposed by Griffin (2002). This enquiry needs similar analyses on all the DSDP and ODP sites in the Mediterranean. However, pending more complete information, we may as a first attempt suppose that brackish waters were pooled within a perched Aegean Basin during the desiccation phase of the Mediterranean. This basin was presumably fed with Paratethyan waters by river transport through the Balkans as suggested by Suc et al. $(2011,2015)$. Momentary overflows above the Hellenic Arc or its partial breaching may have provided such influxes to the almost completely desiccated Mediterranean Basin.

\subsection{Environment of evaporite deposition}

The depositional environment of the Messinian central evaporites is still intensely debated, as conclusive information from cores is very scarce. Hsü et al. (1973) hypothesized a sea-level drop of about $1500 \mathrm{~m}$ and the occurrence of sabkhas at the bottom of desiccated central basins in a warm 
and arid atmosphere. Hardie and Lowenstein (2004) refuted the desiccation model and suggested a water depth deep enough to preclude the bottom from wave activity. Krijgsman and Meijer (2008) considered a completely filled Mediterranean Basin except for a brief desiccation phase when exchanges with the Atlantic Ocean were restricted. This model was also supported by Roveri et al. (2014c) who disproved any sea-level drop greater than $200 \mathrm{~m}$. Bache et al. $(2012,2015)$ defended a scenario where, after a severe sea-level drop, sea level rose progressively in response to erosion of the Gibraltar sill during which the central evaporites were deposited.

In the present study, only Site 134 provides information on the central evaporites, which unfortunately is reduced to the topmost part of their Upper Unit. It cannot be contested that this evaporitic series (362-326 mbsf) corresponds to a low sea level, as reflected by the poor assemblage of calcareous microfossils (foraminifers and nannofossils; Fig. 6). Our data also show that they were deposited in a continuous marine setting but relatively near to the coastline as evidenced by the dinoflagellate cyst assemblages (Fig. 6). The abundance of herbs and particularly of halophytes within the pollen flora denotes the close proximity of the Sardinia shoreline (Fig. 6; Suppl. data 15). It can be concluded that these evaporites did not deposit in a sabkha environment but within a context of low sea level. This interpretation disagrees with the scenarios proposed by Hsü et al. (1973), Krijgsman and Meijer (2008) and Roveri et al. (2014c) but is consistent with the models of Hardie and Lowenstein (2004) and Bache et al. (2012, 2015). In contrast to the assumption by Roveri et al. (2014b), pollen data from the uppermost evaporitic layers of Site 134 display no humid phases during the Lago Mare episodes: dry conditions persisted at low altitude while humidity increased on the relief slope as previously proposed by Fauquette et al. (2006).

\subsection{Pre- and post-reflooding marine environment based on dinoflagellate cysts}

Before the complete reflooding, the Mediterranean Basin probably received Atlantic surface waters overflooding the Gibraltar Sill as proposed by Bache et al. (2015). However, the corresponding dinoflagellate cyst assemblages recorded in holes 976B, 978A and 134B are relatively poor in cyst abundance and diversity when compared to those recorded near the eastern Atlantic palaeo-shoreline at the same time (Bou Regreg, Morocco; Fig. 1; Warny, 1998-1999). In addition, such marine assemblages were momentarily complemented by brackish species originating from overflows of Paratethyan waters or connection with the former Paratethys.

Immediately after the complete reflooding, i.e. after the re-establishment of the MediterraneanAtlantic connection at the same sea-level, marine species became prevalent within the dinoflagellate cyst assemblages of the central Alboran Sea and Balearic Basin (Figs. 3-6). These dinoflagellate cyst assemblages are dominated by Impagidinium spp., Nematosphaeropsis spp., Spiniferites spp., Operculodinium spp., and Lingulodinium machaerophorum, similar to the coeval levels already studied in the nearby Andalucia G1 well by Warny (1998-1999) (Fig. 1). However, these Mediterranean dinoflagellate assemblages are somewhat different from the coeval ones from Bou Regreg (Fig. 1), which for example show a lower abundance of Impagidinium patulum and a greater abundance of Bitectatodinium spp. (Warny, 1998-1999). Such differences likely result from warmer waters in the recovered Mediterranean Sea than in the coastal eastern Atlantic Ocean.

\section{Conclusions}

Our high-resolution multi-proxy biostratigraphic and palaeoenvironmental analysis of sediments including the Messinian-Zanclean boundary in four deep holes has resulted in:

- refining or confirming the exact stratigraphic position of the Messinian-Zanclean boundary in each hole, and that of seismic horizon "M";

- showing that the reflooding of the Mediterranean Basin significantly preceded the Zanclean GSSP (by 128 kyr according to Bache et al. (2012)); 
- identifying several Paratethyan influxes before and after marine reflooding;

- evidencing that the Lago Mare episodes were deposited in a marine context and under dry climatic conditions;

- demonstrating that the Upper Evaporitic Unit of the Balearic Basin was deposited below a water depth relatively close to the Sardinia palaeoshoreline;

- and supporting the two-step scenario of the refilling of the Mediterranean Basin by Atlantic waters (Bache et al., 2012).

After the marine reflooding, the record of oceanic microfossils in the sedimentary archives of the Alboran Sea appears somewhat unstable, probably because of the high turbulence of surface waters before the modern currents were established.

The Paratethyan influxes are time-limited episodes and represent the input of surface waters, needing high sea-level exchanges between the Mediterranean and Paratethys for those preceding or following the peak of the MSC (LM 1 and older episode, LM 3). These influx episodes probably reached littoral areas, allowing the spread of Paratethyan molluscs and ostracods into coastal lagoons, and extending in space and time the invasion by Paratethyan species. Episode LM 2 is included within the topmost part of the Upper Evaporitic Unit or just above it. It is speculated to originate from the overflowing (possibly dumping after barrier collapse) of a perched basin within the Aegean realm that pooled Paratethyan waters during the peak of the MSC.

\section{Acknowledgments}

These investigations have been supported by the French CNRS/INSU Program "Actions Marges" (MedOc) and the TOTAL/Univ. Paris 6 GRI Méditerranée. We thank the Integrated Ocean Drilling Program (IODP) and the Curator of the Bremen Core Repository and its staff for facilities in providing the requested samples. S. Warny and an anonymous referee are thanked for the improvements suggested to our manuscript.

\section{References}

Aguirre, J., Sánchez-Almazo, I.M., 2004. The Messinian post-evaporitic deposits of the Gafares area (Almería-Níjar basin, SE Spain). A new view of the "Lago-Mare" facies. Sediment. Geol. 168, 7195.

Anthonissen, D.E., Ogg, J.G., 2012. Cenozoic and Cretaceous Biochronology of Plankton Foraminifera and Calcareous Nannofossils. In: Gradstein, F.M., Ogg, J.G., Schmitz, M., Ogg, G. (Eds.), The Geologic Time Scale 2012, Elsevier, Amsterdam, pp. 1083-1127.

Archambault-Guézou, J., Ilina, L.B., Keller, J.-P., Montenat, C., 1979 Affinités euxiniques des mollusques messiniens d'Elche (Alicante, Espagne) et implications paléogéographiques. Ann. Géol. Pays Hellén. 1, extra ser., 27-37.

Bache, F., Gargani, J., Suc, J.-P., Gorini, C., Rabineau, M., Popescu, S.-M., Leroux, E., Do Couto, D., Jouannic, G., Rubino, J.-L., Olivet, J.-L., Clauzon, G., Dos Reis, A.T., Aslanian, D., 2015. Messinian evaporite deposition during sea level rise in the Gulf of Lions (Western Mediterranean). Mar. Petrol. Geol., http://dx.doi.org/10.1016/j.marpetgeo.2014.12.013.

Bache, F., Olivet, J.-L., Gorini, F., Rabineau, M., Baztan, J., Aslanian, D., Suc, J.-P., 2009. Messinian Erosional and Salinity Crises: View from the Provence Basin (Gulf of Lions, Western Mediterranean). Earth Planet. Sci. Lett. 286, 139-157.

Bache, F., Popescu, S.-M., Rabineau, M., Gorini, C., Suc, J.-P., Clauzon, G., Olivet, J.-L., Rubino, J.-L., Melinte-Dobrinescu, M.C., Estrada, F., Londeix, L., Armijo, R., Meyer, B., Jolivet, L., Jouannic, G., Leroux, E., Aslanian, D., Dos Reis, A.T., Mocochain, L., Dumurdžanov, N., Zagorchev, I., Lesić, V., Tomić, D., Çağatay, M.N., Brun, J.-P., Sokoutis, D., Csato, I., Ucarkus, 
G., Çakir, Z., 2012. A two-step process for the reflooding of the Mediterranean after the Messinian Salinity Crisis. Bas. Res. 24,125-153.

Benson, R.H., 1973. Psychrospheric and continental ostracoda from ancient sediments in the floor of the Mediterranean. In: Ryan, W.B.F., Hsü, K.J., et al. (Eds.), Initial Reports of Deep Sea Drilling Project 13, U.S. Government Printing Office, Washington, pp. 1002-1008.

Benson, R.H., Hodell, D.A., 1994. Comment on "A critical re-evaluation of the Miocene/Pliocene boundary as defined in the Mediterranean" by F.J. Hilgen and C.G. Langereis. Earth Planet. Sci. Lett. 124, 245-250.

Bernet Rollande, M.C., Cravatte, J., Maurin, A.F., 1979. Nouvelles données sédimentologiques sur les coupes de Carmona et de Vera (Espagne méridionale). 5th Messinian Seminar, Cyprus (Abstract).

Bertini, A., Corradini, D., Suc, J.-P., 1995. On Galeacysta etrusca and the connections between the Mediterranean and the Paratethys. Rom. J. Stratigr. 76 (Suppl. 7(1)), 141-142.

Bertolani Marchetti, D., Accorsi, C., 1978. Palynological studies on samples from DSDP Leg 42A. In: Hsü, K., Montadert, L., et al. (Eds.), Initial Reports of Deep Sea Drilling Project 42(1), U.S. Government Printing Office, Washington, pp. 789-803.

Bertolani Marchetti, D., Cita, M.B., 1975. Palynological investigations on Late Messinian sediments recorded at DSDP Site 132 (Tyrrhenian Basin) and their bearing on the deep basin desiccation model. Riv. Ital. Paleont. 81, 469-470.

Blanc, P.-L., 2002. The opening of the Plio-Quaternary Gibraltar Strait: assessing the size of a cataclysm. Geodin. Acta 15, 303-317.

Bukry, D., 1973. Coccolith stratigraphy Leg 13, Deep Sea Drilling Project. In: Ryan, W.B.F., Hsü, K.J., et al. (Eds.), Initial Reports of Deep Sea Drilling Project 13, U.S. Government Printing Office, Washington, pp. 817-822.

Cambon, G., Suc, J.-P., Aloïsi, J.-C., Giresse, P., Monaco, A., Touzani, A., Duzer, D., Ferrier, J., 1997. Modern pollen deposition in the Rhône delta area (lagoonal and marine sediments), France. Grana 36, 105-113.

Campillo, A., Maldonado, A. Mauffret, A., 1992. Stratigraphic and tectonic evolution of the western Alboran Sea: Late Miocene to Recent. Geo-Mar. Lett. 12, 165-172.

Carnevale, G., Caputo, D., Landini, W., 2006a. Late Miocene fish otoliths from the Colombacci Formation (Northern Apennines, Italy): Implications for the Messinian 'Lago-mare' event. Geol. J. 41, 1-19.

Carnevale, G., Landini, W., Sarti, G., 2006b. Mare versus Lago-mare: marine fishes and the Mediterranean environment at the end of the Messinian Salinity Crisis. Journ. Geol. Soc. London $163,75-80$.

Castradori, D., 1998. Calcareous nannofossils in the basal Zanclean of the Eastern Mediterranean Sea: Remarks on paleoceanography and sapropel formation. In: Robertson, A.H.F., Emeis, K.C., Richter, C., Camerlenghi, A. (Eds.), Proceedings of the Ocean Drilling Program, Scientific Results 160, Ocean Drilling Program, College Station, Texas, pp. 113-123.

Cavazza, W., DeCelles, P.G., 1998. Upper Messinian siliciclastic rocks in southeastern Calabria (southern Italy): palaeotectonic and eustatic implications for the evolution of the central Mediterranean region. Tectonophysics 298, 223-241.

CIESM (Antón, J., Çağatay, M.N., De Lange, G., Flecker, R., Gaullier, V., Gunde-Cimerman, N., Hübscher, C., Krijgsman, W., Lambregts, P., Lofi, J., Lugli, S., Manzi, V., McGenity, T.J., Roveri, M., Sierro, F.J., Suc J.-P.), 2008. Executive Summary. In: Briand, F. (Ed.), The Messinian Salinity Crisis from mega-deposits to microbiology - A consensus report. CIESM Workshop Monographs 33, 7-28.

Cita M.B., 1973. Pliocene biostratigraphy and chronostratigraphy. In: Ryan, W.B.F., Hsü, K.J., al. (Eds.), Initial Reports of Deep Sea Drilling Project 13, U.S. Government Printing Office, Washington, pp. 1343-1379. 
Cita, M.B., Colombo, L., 1979. Sedimentation in the latest Messinian at Capo Rossello (Sicily). Sedimentology 26, 497-522.

Cita, M.B., Vismara Schilling, A., Bossio, A., 1980. Stratigraphy and paleoenvironment of the Cuevas del Almanzora section (Vera basin). A re-interpretation. Riv. Ital. Paleont. 86(1), 215240.

Clauzon, G., Suc, J.-P., Gautier, F., Berger, A., Loutre, M.-F., 1996. Alternate interpretation of the Messinian salinity crisis: Controversy resolved? Geology 24(4), 363-366.

Clauzon, G., Suc, J.-P., Do Couto, D., Jouannic, G., Melinte-Dobrinescu, M.C., Jolivet, L., Quillévéré, F., Lebret, N., Mocochain, L., Popescu, S.-M., Martinell, J., Doménech, R., Rubino, J.-L., Gumiaux, C., Warny, S., Bellas, S.M., Gorini, C., Bache, F., Rabineau, M., Estrada, F., 2015. New insights on the Sorbas Basin (SE Spain): the onshore reference of the Messinian Salinity Crisis. Mar. Petrol. Geol. this issue, http://dx.doi.org/10.1016/j.marpetgeo.2015.02.016.

Clauzon, G., Suc, J.-P., Popescu, S.-M., Marunteanu, M., Rubino, J.-L., Marinescu, F., Melinte, M.C., 2005. Influence of the Mediterranean sea-level changes over the Dacic Basin (Eastern Paratethys) in the Late Neogene. The Mediterranean Lago Mare facies deciphered. Bas. Res. 17, 437-462.

Comas, M.C., García-Dueñas, V., Jurado, M.J., 1992. Neogene tectonic evolution of the Alboran Sea from MCS Data. Geo-Mar. Lett., 12(2), 157-164.

Cornée, J.-J., Ferrandini, M., Saint Martin, J.P., Münch, P., Moullade, M., Ribaud-Laurenti, A., Roger, S., Saint Martin, S., Ferrandini, J., 2006. The late Messinian erosional surface and the subsequent reflooding in the Mediterranean: new insights from the Melilla-Nador basin (Morocco). Palaeogeogr. Palaeoclimatol. Palaeoecol. 230, 129-154.

Decima, A., Wezel, F.C., 1971. Osservazioni sulle evaporiti messiniane della Sicilia centro meridionale. Riv. Miner. Sicil. 130-132, 171-187.

Di Stefano, A., Sturiale, G., 2010. Refinements of calcareous nannofossil biostratigraphy at the Miocene/Pliocene boundary in the Mediterranean region. Geobios 43, 5-20.

Do Couto, D., Popescu, S.-M., Suc, J.-P., Melinte-Dobrinescu, M.C., Barhoun, N., Gorini, C., Jolivet, L., Poort, J., Jouannic, G., Auxietre, J.-L., 2014. Lago Mare and the Messinian Salinity Crisis: Evidences from the Alboran Sea (S. Spain). Mar. Petrol. Geol. 52, 57-76.

Estrada, F., Ercilla, G., Gorini, C., Alonso, B., Vázquez, J.T., Garcia-Castellanos, D., Juan, C., Maldonado, A., Ammar, A., Elabbassi, M., 2011. Impact of pulsed Atlantic water inflow into the Alboran Basin at the time of the Zanclean flooding. Geo-Mar. Lett. 31, 361-376.

Fauquette, S., Suc, J.-P., Bertini, A., Popescu, S.-M., Warny, S., Bachiri Taoufiq, N., Perez Villa, M.-J., Chikhi, H., Subally, D., Feddi, N., Clauzon, G., Ferrier, J., 2006. How much did climate force the Messinian salinity crisis? Quantified climatic conditions from pollen records in the Mediterranean region. Palaeogeogr., Palaeoclimatol., Palaeoecol. 238, 1-4, 281-301.

Feddi, N., Fauquette, S., Suc, J.-P., 2011. Histoire plio-pléistocène des écosystèmes végétaux de Méditerranée sud-occidentale: apport de l'analyse pollinique de deux sondages en mer d'Alboran. Geobios 44, 57-69.

Fortuin, A.R., Kelling, J.M.F., Roep, Th.B., 1995. The enigmatic Messinian-Pliocene section of Cuevas del Almanzora (Vera basin, SE Spain) revisited - erosional features and strontium isotope ages. Sediment. Geol. 97, 177-201.

Garcés, M., Krijgsman, W., Agustí, J., 1998. Chronology of the late Turolian deposits of the Fortuna basin (SE Spain): implications for the Messinian evolution of the eastern Betics. Earth Planet. Sci. Lett. 163, 69-81.

Garcia-Castellanos, D., Estrada, F., Jiménez-Munt, I., Gorini, C., Fernàndez, M., Vergés, J., De Vicente, R., 2009. Catastrophic flood of the Mediterranean after the Messinian salinity crisis. Nature 462, 778-782. 
Gartner, S., Jr., 1973. Calcareous nannofossil age determinations, Deep Sea Drilling Project, Leg 13. In: Ryan, W.B.F., Hsü, K.J., et al. (Eds.), Initial Reports of Deep Sea Drilling Project 13, U.S. Government Printing Office, Washington, pp. 822-827.

Gignoux, M., 1950. Géologie Stratigraphique, Masson \& $C^{\text {ie }}$ (Ed.), 4th ed., p. 735, Paris.

Gorini, C., Lofi, J., Duvail, C., Dos Reis, A.T., Guennoc, P., Lestrat P., Mauffret, A., 2005. The Late Messinian salinity crisis and Late Miocene tectonism: Interaction and consequences on the physiography and post-rift evolution of the Gulf of Lions margin. Mar. Petrol. Geol. 22, 695712.

Griffin, D.L., 2002. Aridity and humidity: two aspects of the late Miocene climate of North Africa and the Mediterranean. Palaeogeogr., Palaeoclimatol., Palaeoecol. 182, 65-91.

Guerra-Merchán, A., Serrano, F., Garcés, M., Gofas, S., Esu, D., Gliozzi, E., Grossi, F., 2010. Messinian Lago-Mare deposits near the Strait of Gibraltar (Malaga Basin, S. Spain). Palaeogeogr. Palaeoclimatol. Palaeoecol. 285, 264-276.

Hardie L.A., Lowenstein, T.K., 2004. Did the Mediterranean Sea dry out during the Miocene? A reassessment of the evaporite evidence from DSDP Legs 13 and 42A cores. Journ. Sediment. Res. 74, 4, 453-461.

Hsü, K.J., Cita, M.B., Ryan, W.B.F., 1973. The origin of the Mediterranean evaporites. In: Ryan, W.B.F., Hsü, K.J., et al. (Eds.), Initial Reports of Deep Sea Drilling Project 13, U.S. Government Printing Office, Washington, pp. 1203-1231.

Iaccarino, S., Bossio, A., 1999. Paleoenvironment of uppermost Messinian sequences in the Western Mediterranean (Sites 974, 975, and 978). In: Zahn, R., Comas, M.C., Klaus, A. (Eds.), Proceedings of the Ocean Drilling Program, Scientific Results 161, Ocean Drilling Program, College Station, Texas, pp. 529-541.

Iaccarino, S.M., Cita, M.B., Gaboardi, S., Gruppini, G.M., 1999. High-resolution biostratigraphy at the Miocene/Pliocene boundary in holes 974B and 975B, Western Mediterranean. In: Zahn, R., Comas, M.C., Klaus, A. (Eds.), Proceedings of the Ocean Drilling Program, Scientific Results 161, Ocean Drilling Program, College Station, Texas, pp. 197-221.

Iaccarino, S.M., Premoli Silva, I., Biolzi, M., Foresi, L.M., Lirer, F., Turco, E., Petrizzo, M.R., 2007. Practical manual of Neogene planktonic foraminifera. Università di Perugia Press, $180 \mathrm{pp}$.

Krijgsman, W., 2002. The Mediterranean: Mare Nostrum of Earth sciences. Earth Planet. Sci. Lett. $205,1-12$.

Krijgsman, W., Hilgen, F.J., Raffi, I., Sierro, F.J., Wilson, D.S., 1999. Chronology, causes and progression of the Messinian salinity crisis. Nature 400, 652-655.

Krijgsman W., Meijer, P.Th., 2008. Depositional environments of the Mediterranean "Lower Evaporites" of the Messinian salinity crisis: Constraints from quantitative analyses. Mar. Geol. 253, 73-81.

Lancis, C., Flores, J.-A., 2007. A new biostratigraphically significant calcareous nannofossil species in the Early Pliocene of the Mediterranean. Micropaleontology 52(5), 477-481.

Lofi, J., Sage, F., Déverchère, J., Loncke, L., Maillard, A., Gaullier, V., Thinon, I., Gillet, H., Guennoc, P., Gorini, C., 2011. Refining our knowledge of the Messinian salinity crisis records in the offshore domain through multi-site seismic analysis. Bull. Soc. Géol. France 182(2), 163180.

Londeix, L., Benzakour, M., Suc, J.-P., Turon, J.-L., 2007. Messinian paleoenvironments and hydrology in Sicily (Italy): The dinoflagellate cyst record. Geobios 40(3), 233-250.

Lourens, L.J., Hilgen, F.J., Laskar, J., Shackleton, N.J., Wilson, D., 2005. The Neogene period. In: Gradstein, F.M., Ogg, J.G., Smith, A.G. (Eds.), A geological Time Scale 2004. Cambridge University Press, Cambridge, pp. 409-440.

Martini, E., 1971. Standard Tertiary and Quaternary calcareous nannoplankton zonation. In: Farinacci, A. (Ed.), Proceedings of the 2nd International Conference on Planktonic Microfossils, Roma 1970, vol. 2. Editura Tecnoscienza, Rome, pp. 739-785. 
Melinte-Dobrinescu, M.C., Suc, J.-P., Clauzon, G., Popescu, S.-M., Armijo, R., Meyer, B., Biltekin, D., Çağatay, M.N., Ucarkus, G., Jouannic, G., Fauquette, S., Çakir, Z., 2009. The Messinian Salinity Crisis in the Dardanelles region: Chronostratigraphic constraints. Palaeogeogr., Palaeoclimatol., Palaeoecol 278, 24-39.

Orszag-Sperber, F., 2006. Changing perspectives in the concept of "Lago-Mare" in Mediterranean Late Miocene evolution. Sediment. Geol. 188-189, 259-277.

Perch-Nielsen, K., 1985. Cenozoic calcareous nannofossils. In: Bolli, H.M., Saunders, J.B., PerchNielsen, K. (Eds.), Plankton Stratigraphy, vol. 1. Cambridge University Press, Cambridge, pp. 427-554.

Pierre, C., Caruso, A., Blanc-Valleron, M.-M., Rouchy J.M., Orszag-Sperber, F., 2006. Reconstruction of the paleoenvironmental changes around the Miocene-Pliocene boundary along a West-East transect across the Mediterranean. Sediment. Geol. 188-189, 319-340.

Popescu, S.-M., Dalesme, F., Jouannic, G., Escarguel, G., Head, M.J., Melinte-Dobrinescu, M.C., Sütö-Szentai, M., Bakrac, K., Clauzon, G., Suc, J.-P., 2009. Galeacysta etrusca complex, dinoflagellate cyst marker of Paratethyan influxes into the Mediterranean Sea before and after the peak of the Messinian Salinity Crisis. Palynology 33(2), 105-134.

Raffi, I., Backman, J., Fornaciari, E., Pälike, H., Rio, D., Lourens, L., Hilgen, F., 2006. A review of calcareous nannofossil astrobiochronology encompassing the past 25 million years. Quat. Sci. Rev. 25, 3113-3137.

Roveri, M., Flecker, R., Krijgsman, W., Lofi, J., Lugli, S., Manzi, V., Sierro, F.J., Bertini, A., Camerlenghi, A., De Lange, G., Govers, R., Hilgen, F.J., Hübscher, C., Meijer, P.Th., Stoica, M., 2014a. The Messinian Salinity Crisis: Past and future of a great challenge for marine sciences. Mar. Geol. 352, 25-58.

Roveri, M., Lugli, S., Manzi, V., Gennari, R., Schreiber, R.C., 2014b. High-resolution strontium isotope stratigraphy of the Messinian deep Mediterranean basins: Implications for marginal to central basins correlation. Mar. Geol. 349, 113-125.

Roveri, M., Manzi, V., Bergamasco, A., Falcieri, F.M., Gennari, R., Lugli, S., Schreiber, B.C., 2014c. Dense shelf water cascading and Messinian canyons: A new scenario for the Mediterranean Salinity Crisis. Amer. Journ. Sci. 314, 751-784.

Ruggieri, G., 1962. La serie marina pliocenica e quaternaria della Val Marecchia. In: Atti dell'Academia di Scienze, Lettere e Arti di Palermo, vol. 19, pp. 1-169.

Ryan, W.B.F., Hsü, K.J., Cita, M.B., Dumitrica, P., Lort, J., Mayne, W., Nesteroff, W.D., Pautot, G., Stradner, H., Wezel, F.C., 1973. Boundary of Sardinia slope with Balearic abyssal plain Sites 133 and 134. In: Ryan, W.B.F., Hsü, K.J., et al. (Eds.), Initial Reports of Deep Sea Drilling Project 13, U.S. Government Printing Office, Washington, pp. 465-514.

Sage, F., Von Gronefeld, G., Déverchère, J., Gaullier, V., Maillard, A., Gorini C., 2005. Seismic evidence for Messinian detrital deposits at the western Sardinia margin, northwestern Mediterranean. Mar. Petrol. Geol. 22, 757-773.

Serrano, F., González-Donoso, J.M., Linares, D., 1999. Biostratigraphy and paleoceanography of the Pliocene at Sites 975 (Menorca Rise) and 976 (Alboran Sea) from a quantitative analysis of the planktonic foraminiferal assemblages. In: Zahn, R., Comas, M.C., Klaus, A. (Eds.), Proceedings of the Ocean Drilling Program, Scientific Results 161, Ocean Drilling Program, College Station, Texas, pp. 185-195.

Siesser, W.G., de Kaenel, E.P., 1999. Neogene calcareous nannofossils: Western Mediterranean biostratigraphy and paleoclimatology. In: Zahn, R., Comas, M.C., Klaus, A. (Eds.), Proceedings of the Ocean Drilling Program, Scientific Results 161, Ocean Drilling Program, College Station, Texas, pp. 223-237.

Soria, J.M., Caracuel, J.E., Corbí, H., Dinarès-Turell, J., Lancis, C., Tent-Manclús, J.E., Yébenes, A., 2008. The Bajo Segura Basin (SE Spain): implications for the Messinian salinity crisis in the Mediterranean margins. Stratigraphy 5(3-4), 257-263. 
Spaak, P., 1983. Accuracy in correlation and ecological aspects of the planktonic foraminiferal zonation of the Mediterranean Pliocene. Utrecht Micropaleontol. Bull. 28, 5-160.

Spezzaferri, S., Cita, M.B., McKenzie, J.A., 1998. The Miocene/Pliocene boundary in the Eastern Mediterranean: Results from sites 967 and 969. In: Robertson, A.H.F., Emeis, K.-C., Richter, C., Camerlenghi, A. (Eds.), Proceedings of the Ocean Drilling Program, Scientific Results 160, Ocean Drilling Program, College Station, Texas, pp. 9-28.

Suc, J.-P., Do Couto, D., Melinte-Dobrinescu, M.C., Macaleţ, R., Quillévéré, F., Clauzon, G., Csato, I., Rubino, J.-L., Popescu, S.-M., 2011. The Messinian Salinity Crisis in the Dacic Basin (SW Romania) and early Zanclean Mediterranean - Paratethys high sea-level connection. Palaeogeogr., Palaeoclimatol., Palaeoecol. 310, 256-272.

Suc, J.-P., Fauquette, S., Bessedik, M., Bertini, A., Zheng, Z., Clauzon, G., Suballyova, D., Diniz, F., Quézel, P., Feddi, N., Clet, M., Bessais, E., Bachiri Taoufiq, N., Méon, H., CombourieuNebout, N., 1999. Neogene vegetation changes in West European and West circumMediterranean areas. In: Agustí, J., Rook, L., Andrews, P. (Eds.), Hominid Evolution and Climate in Europe, 1 Climatic and Environmental Change in the Neogene of Europe, Cambridge University Press, Cambridge, 370-385.

Suc, J.-P., Popescu, S.-M., Do Couto, D., Clauzon, G., Rubino, J.-L., Melinte-Dobrinescu, M.C., Quillévéré, F., Brun, J.-P., Dumurdžanov, N., Zagorchev, I., Lesić, V., Tomić, D., Sokoutis, D., Meyer, B., Macaleţ, R., Jelen, B., Rifelj, H., 2015. Marine gateway vs. fluvial stream within the Balkans from 6 to 5 Ma. Mar. Petrol. Geol. this issue,

http://dx.doi.org/10.1016/j.marpetgeo.2015.01.003.

Warny, S., 1998-1999. Mio-Pliocene palynology of the Gibraltar Arc: A new perspective on the Messinian Salinity Crisis (PhD Thesis). Univ. catholique Louvain, p. 307.

Warny, S., Bart, P.J., Suc, J.-P., 2003. Timing and progression of climatic, tectonic and glacioeustatic influences on the Messinian Salinity Crisis. Palaeogeogr., Palaeoclimatol., Palaeoecol. 202, 59-66.

Warny, S.A, Wrenn, J.H., 2002. Upper Neogene dinoflagellate cysts of the Atlantic coast of Morocco. Micropaleontol. 48(3), 257-272.

Zahn, R., Comas, M.C., Klaus, A., Aubourg, C., Belanger, P.E., Bernasconi, S.M., Cornell, W., de Kaenel, E.P., de Larouzière, F.D., Doglioni, C., Doose, H., Fukusawa, H., Hobart, M., Iaccarino, S.M., Ippach, P., Marsaglia, K., Meyers, P., Murat, A., O’Sullivan, G.M., Platt, J.P., Prasad, M., Siesser, W.G., Skilbeck, C.G., Soto, J.I., Tandon, K., Torii, M., Tribble, J.S., Wilkens, R.H., 1996a. Site 976. In: Zahn, R., Comas, M.C., Klaus, A. (Eds.), Proceedings of the Ocean Drilling Program, Initial Reports 161, Ocean Drilling Program, College Station, Texas, pp. 179-297.

Zahn, R., Comas, M.C., Klaus, A., Aubourg, C., Belanger, P.E., Bernasconi, S.M., Cornell, W., de Kaenel, E.P., de Larouzière, F.D., Doglioni, C., Doose, H., Fukusawa, H., Hobart, M., Iaccarino, S.M., Ippach, P., Marsaglia, K., Meyers, P., Murat, A., O’Sullivan, G.M., Platt, J.P., Prasad, M., Siesser, W.G., Skilbeck, C.G., Soto, J.I., Tandon, K., Torii, M., Tribble, J.S., Wilkens, R.H., 1996b. Site 976: Core description forms and core photographs. In: Zahn, R., Comas, M.C., Klaus, A. (Eds.), Proceedings of the Ocean Drilling Program, Initial Reports 161, Ocean Drilling Program, College Station, Texas, pp. 577-767.

Zahn, R., Comas, M.C., Klaus, A., Aubourg, C., Belanger, P.E., Bernasconi, S.M., Cornell, W., de Kaenel, E.P., de Larouzière, F.D., Doglioni, C., Doose, H., Fukusawa, H., Hobart, M., Iaccarino, S.M., Ippach, P., Marsaglia, K., Meyers, P., Murat, A., O’Sullivan, G.M., Platt, J.P., Prasad, M., Siesser, W.G., Skilbeck, C.G., Soto, J.I., Tandon, K., Torii, M., Tribble, J.S., Wilkens, R.H., 1996c. Site 977. In: Zahn, R., Comas, M.C.,

Klaus, A. (Eds.), Proceedings of the Ocean Drilling Program, Initial Reports 161, Ocean Drilling Program, College Station, Texas, pp. 299-353.

Zahn, R., Comas, M.C., Klaus, A., Aubourg, C., Belanger, P.E., Bernasconi, S.M., Cornell, W., de Kaenel, E.P., de Larouzière, F.D., Doglioni, C., Doose, H., Fukusawa, H., Hobart, M., Iaccarino, 
S.M., Ippach, P., Marsaglia, K., Meyers, P., Murat, A., O’Sullivan, G.M., Platt, J.P., Prasad, M., Siesser, W.G., Skilbeck, C.G., Soto, J.I., Tandon, K., Torii, M., Tribble, J.S., Wilkens, R.H., 1996d. Site 978. In: Zahn, R., Comas, M.C., Klaus, A. (Eds.), Proceedings of the Ocean Drilling Program, Initial Reports 161, Ocean Drilling Program, College Station, Texas, pp. 355-388.

Zecchin, M., Civile, D., Caffau, M., Muto, F., Di Stefano, A., Maniscalco, R., Critelli, S., 2013. The Messinian succession of the Crotone Basin (southern Italy). I: Stratigraphic architecture reconstructed by seismic and well data. Mar. Petrol. Geol. 48, 455-473.

Zeeden, C., Hilgen, F., Westerhold, T., Lourens, L., 2013. Revised Miocene splice, astronomical tuning and calcareous plankton biochronology of ODP Site 926 between and $14.4 \mathrm{Ma}$. Palaeogeogr., Palaeoclimatol., Palaeoecol. 369, 430-451.

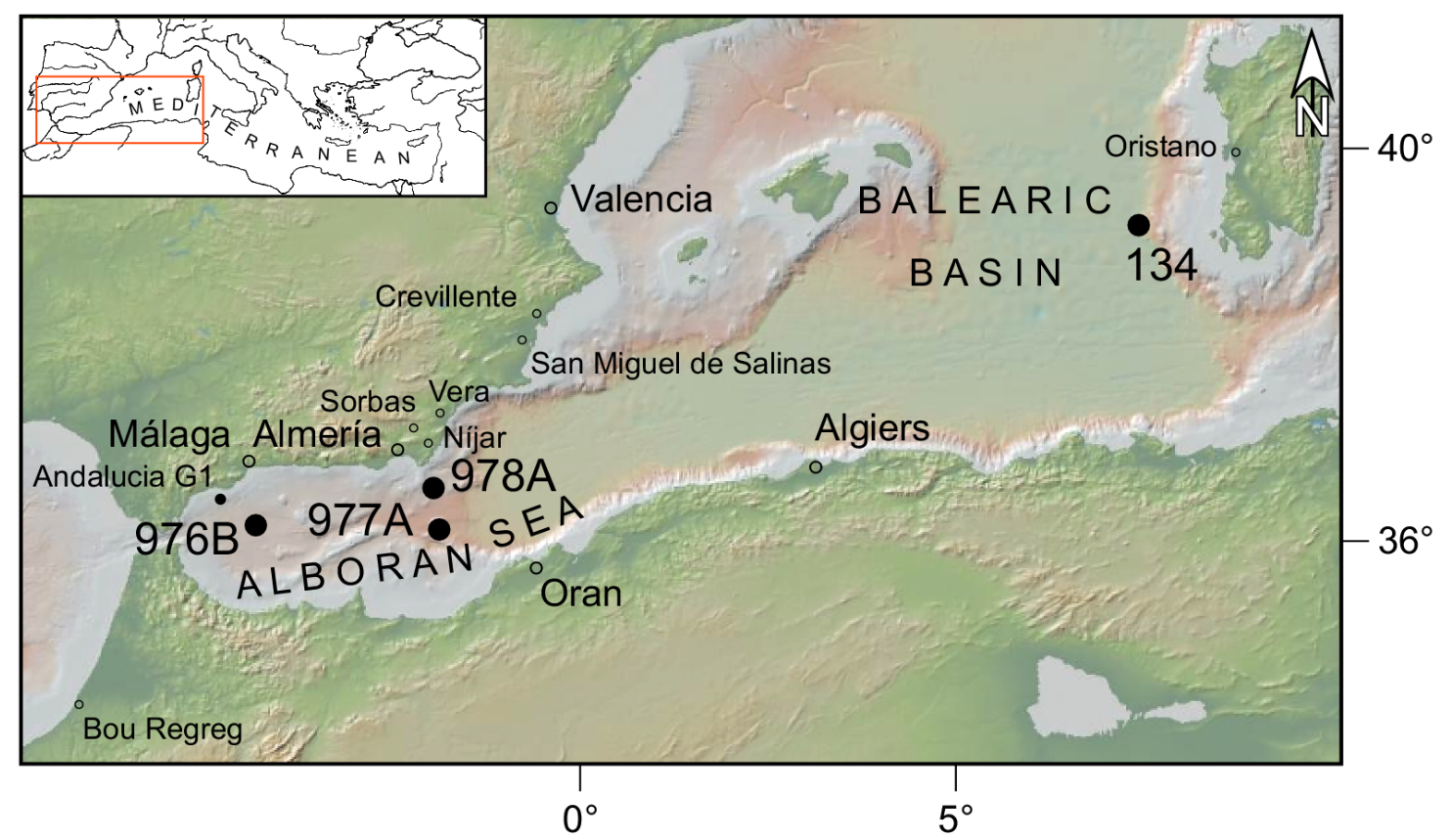

Fig. 1. Location of the four studied boreholes and comparative localities. 


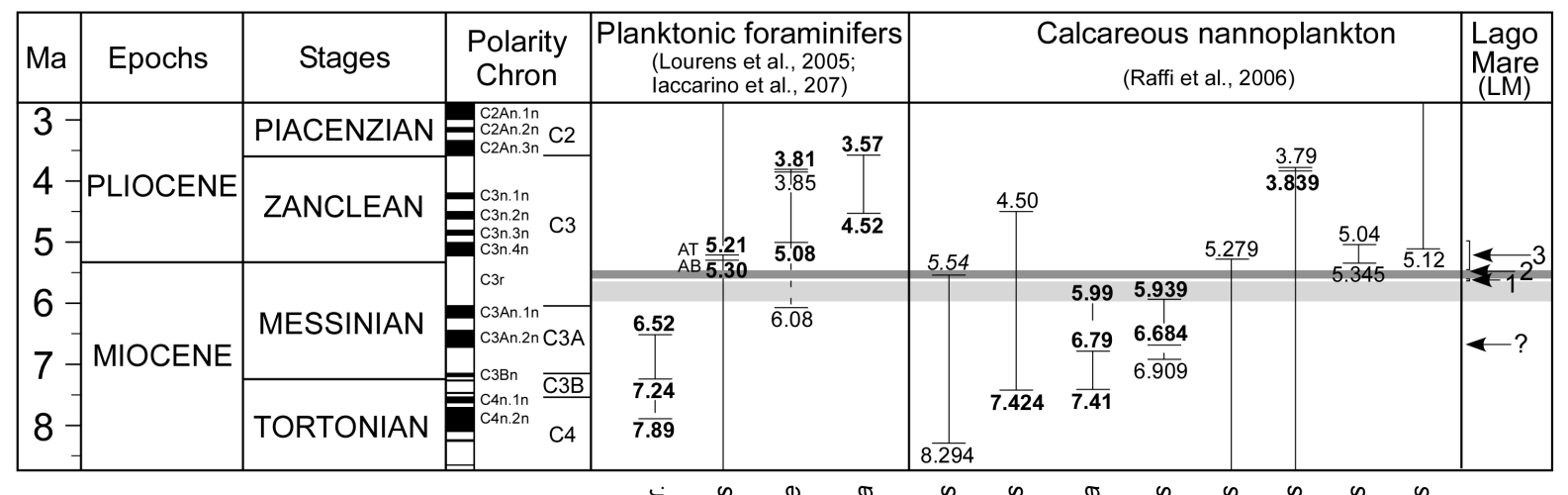

\begin{tabular}{|c|}
\hline $\begin{array}{l}5.46 \quad 2^{\text {nd }} \text { step (peak) of the MSC (central basins) } \\
5.60-155 \\
5.96 \quad 1^{\text {st }} \text { step of the MSC (peripheral basins) } \\
\end{array}$ \\
\hline $\begin{array}{l}\text { Mediterranean ages are in bold characters } \\
\text { Global ages are in normal characters } \\
\text { Similar global and Mediterranean ages are in italics } \\
\text { AB, acme base AT, acme top }\end{array}$ \\
\hline
\end{tabular}

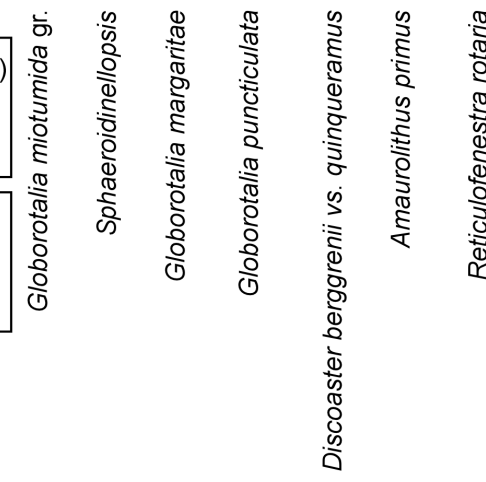

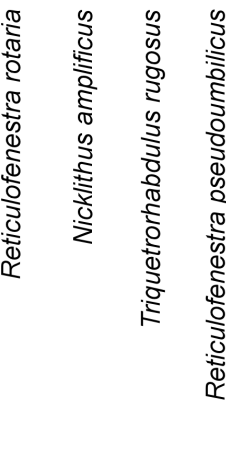

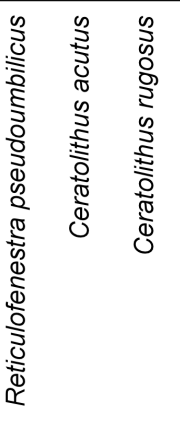

Fig. 2. Bio-chronostratigraphic scheme of the referred markers among planktonic foraminifers and calcareous nannofossils. Chronostratigraphic position of the Lago Mare (LM) events. The ages indicated for Reticulofenestra rotaria are from Lourens et al. (2005). 


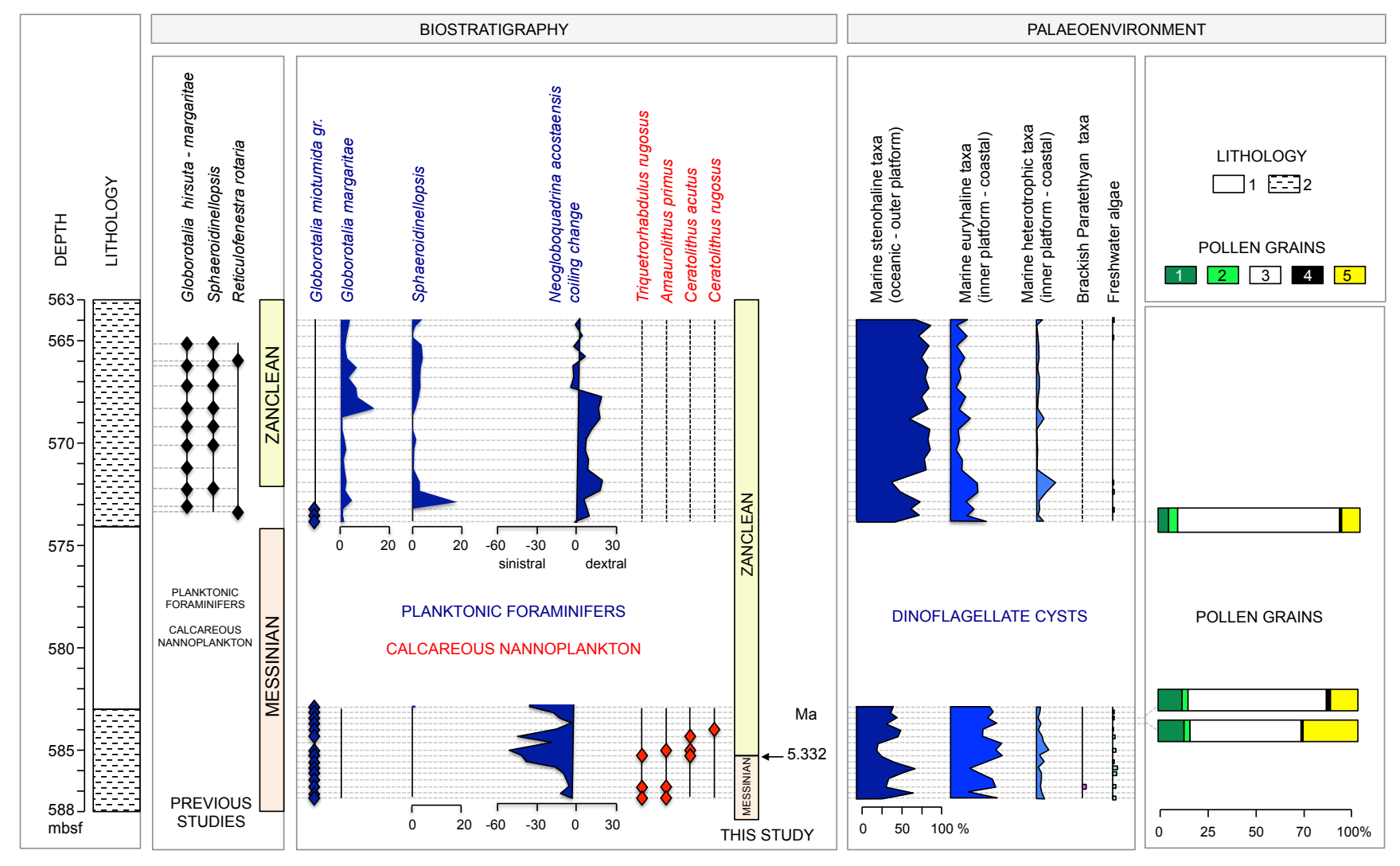

Fig. 3. ODP Hole 976B: Biostratigraphic results (planktonic foraminifers, calcareous nannoplankton) compared to previous data (Serrano et al., 1999; Siesser and de Kaenel, 1999), and palaeoenvironmental results (dinoflagellate cysts and pollen grains).

Lithology: 1, void; 2, clays.

Pollen groups (see Supplementary data 4 for details): 1, Tropical and subtropical elements; 2, Warm-temperate elements; 3, Pinus and indeterminable pollen grains of Pinaceae; 4, Mid- and high-altitude trees; 5, Herbs including steppe elements. 


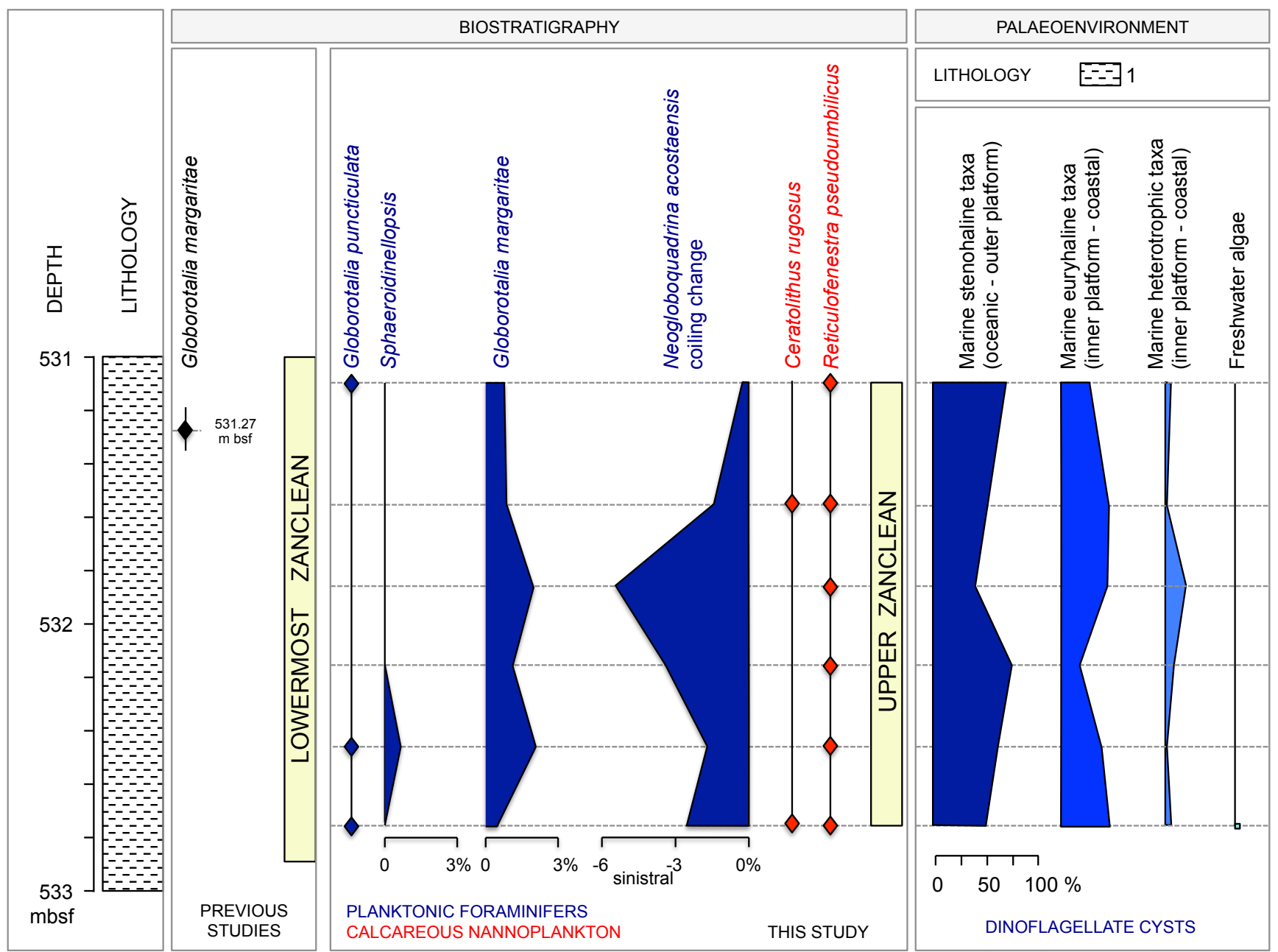

Fig. 4. ODP Hole 977A: Biostratigraphic results (planktonic foraminifers, calcareous nannoplankton) compared to previous data (Zahn et al., 1996a, b, c, d; Siesser and de Kaenel, 1999), and palaeoenvironmental results (dinoflagellate cysts).

Lithology: 1, clays.

Foraminifer relative frequency is in percentages. 

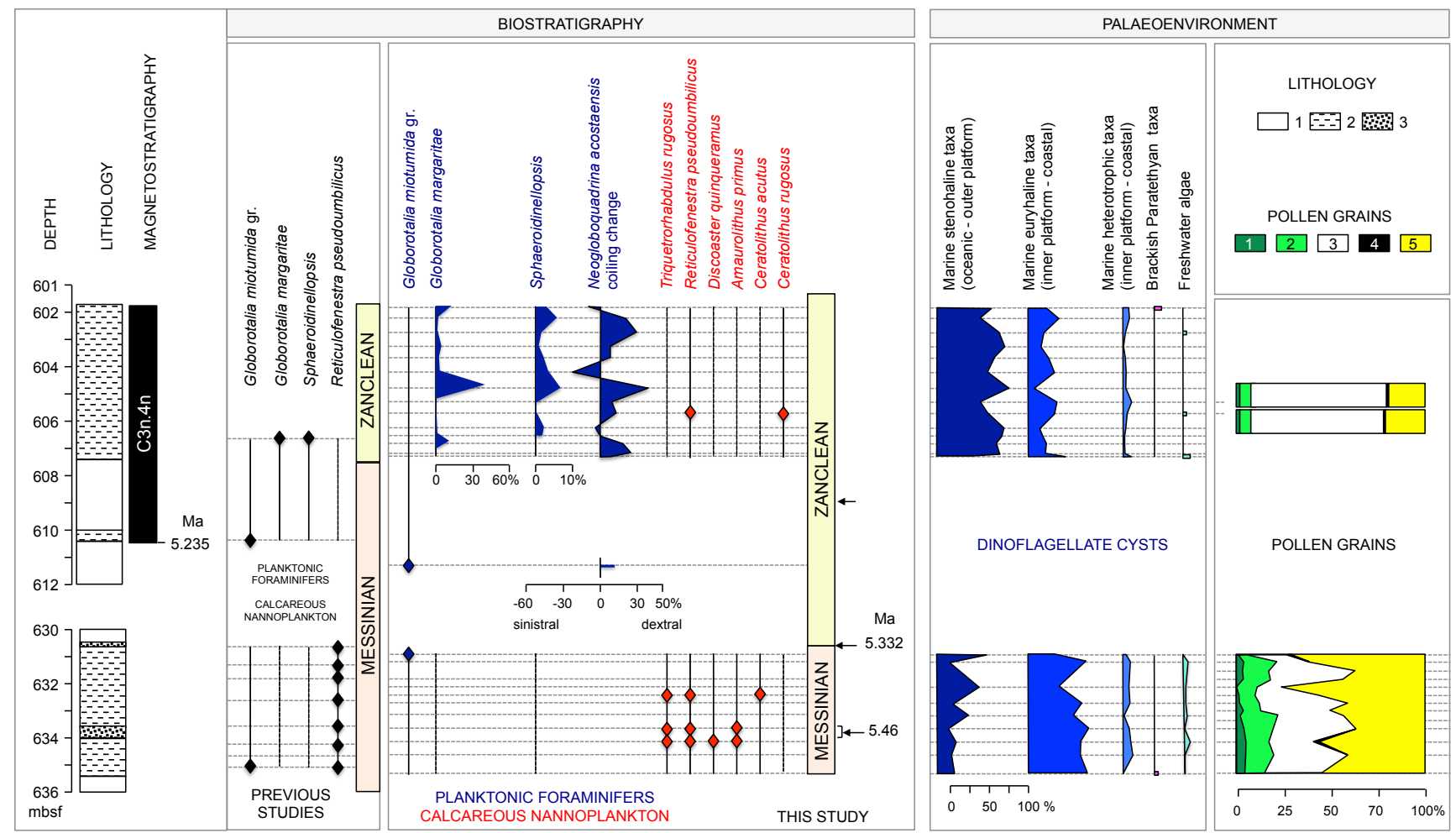

Fig. 5. ODP Hole 978A: Biostratigraphic results (planktonic foraminifers, calcareous nannoplankton) compared to previous data (Zahn et al., 1996a, b, c, d; Iaccarino and Bossio, 1999; Siesser and de Kaenel, 1999), and palaeoenvironmental results (dinoflagellate cysts and pollen grains).

Lithology: 1, void; 2 , chalky clays; 3 , gravels to pebbles.

Foraminifer relative frequency is in percentages.

Pollen groups (see Supplementary data 11 for details) refer to Figure 3. 


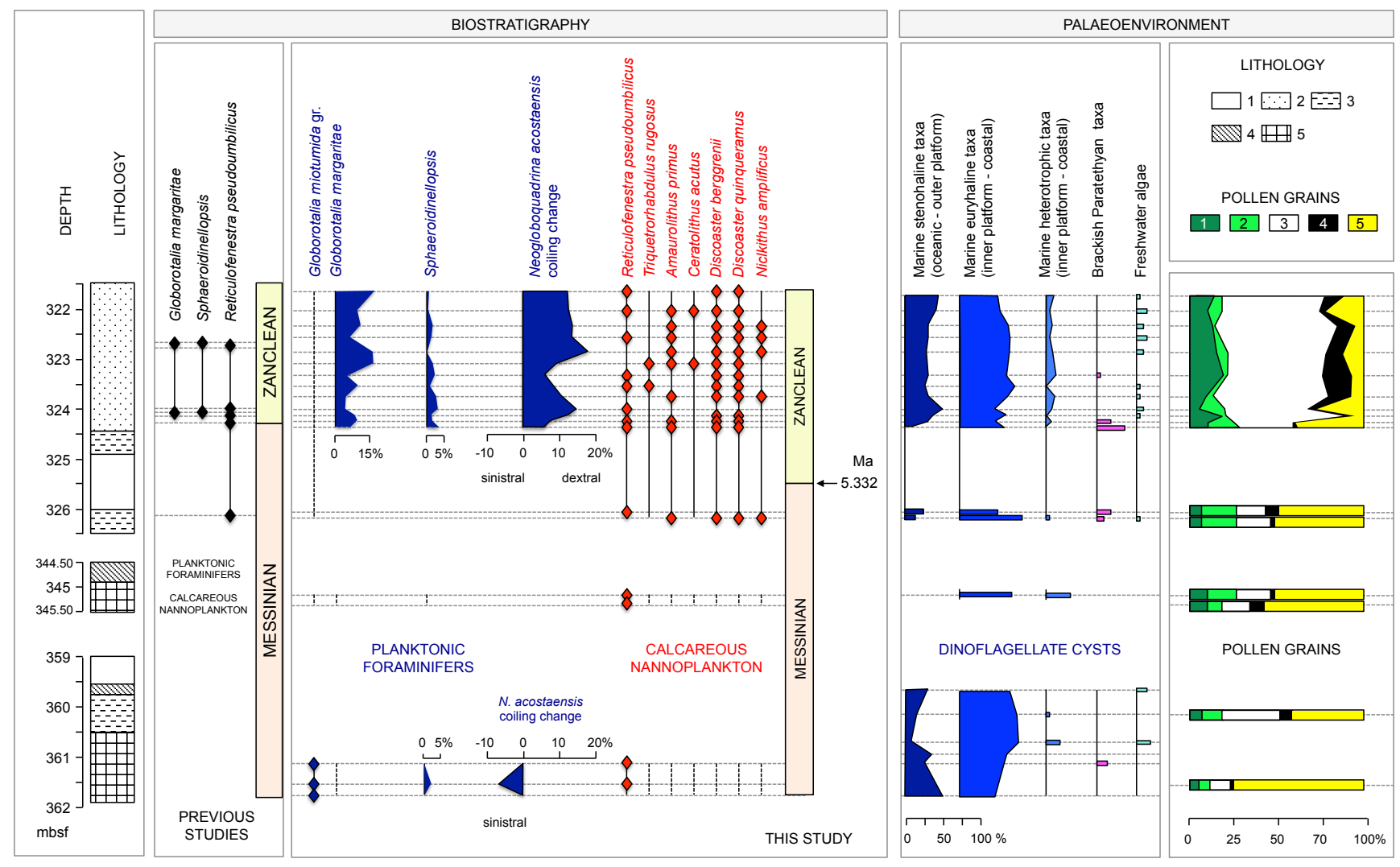

Fig. 6. Hole 134B: Biostratigraphic results (planktonic foraminifers, calcareous nannoplankton) compared to previous data (Cita, 1973), and palaeoenvironmental results (dinoflagellate cysts and pollen grains).

Lithology: 1, void; 2, marls with gravels; 3, dolomitic marls; 4, anhydrite; 5, halite.

Foraminifer relative frequency is in percentage.

Pollen groups (see Supplementary data 15 for details) refer to Figure 3. 


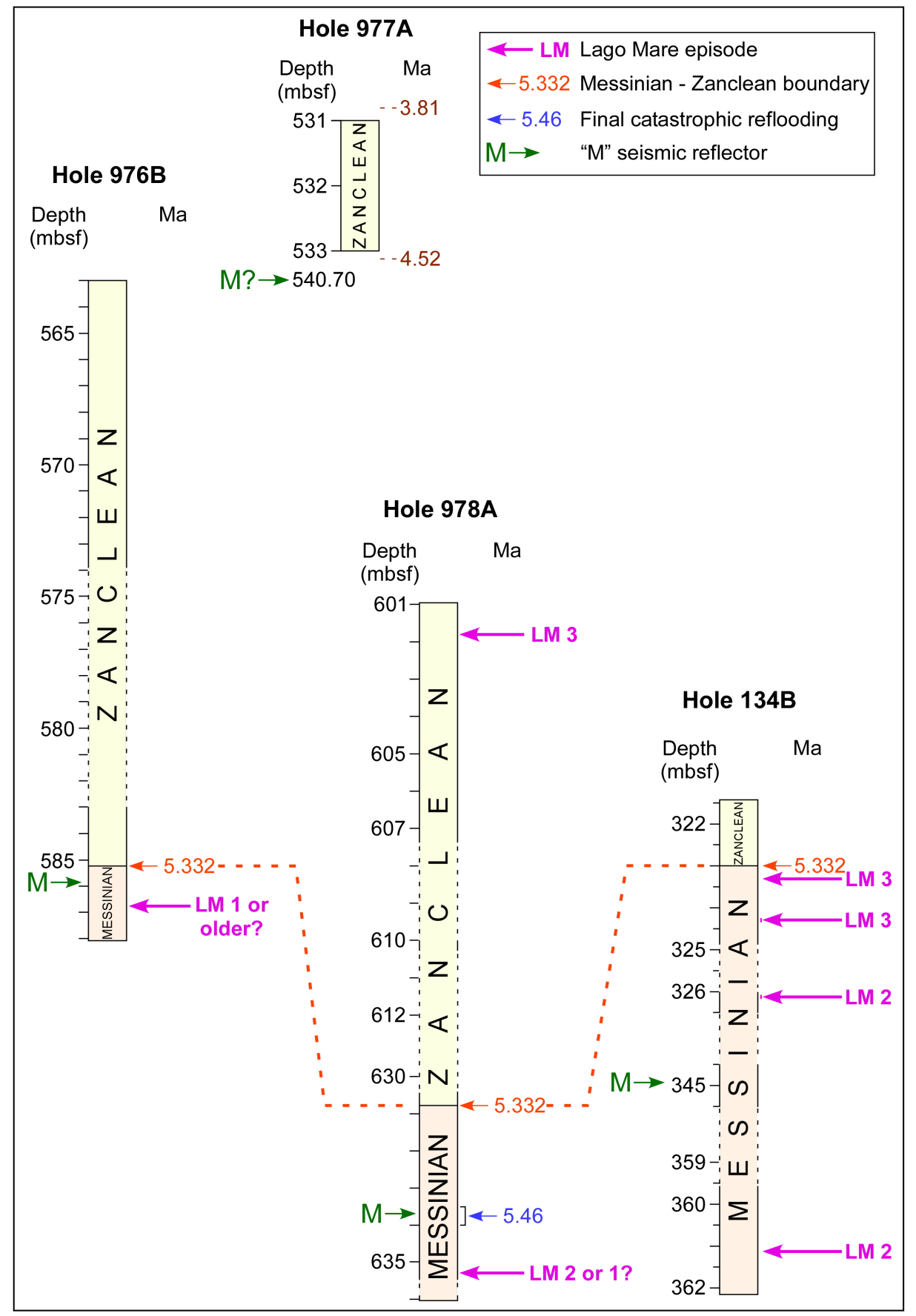

Fig. 7. Proposed chronostratigraphy of the studied holes for the interval including the seismic reflector "M" with the positions of recorded Lago Mare episodes. 


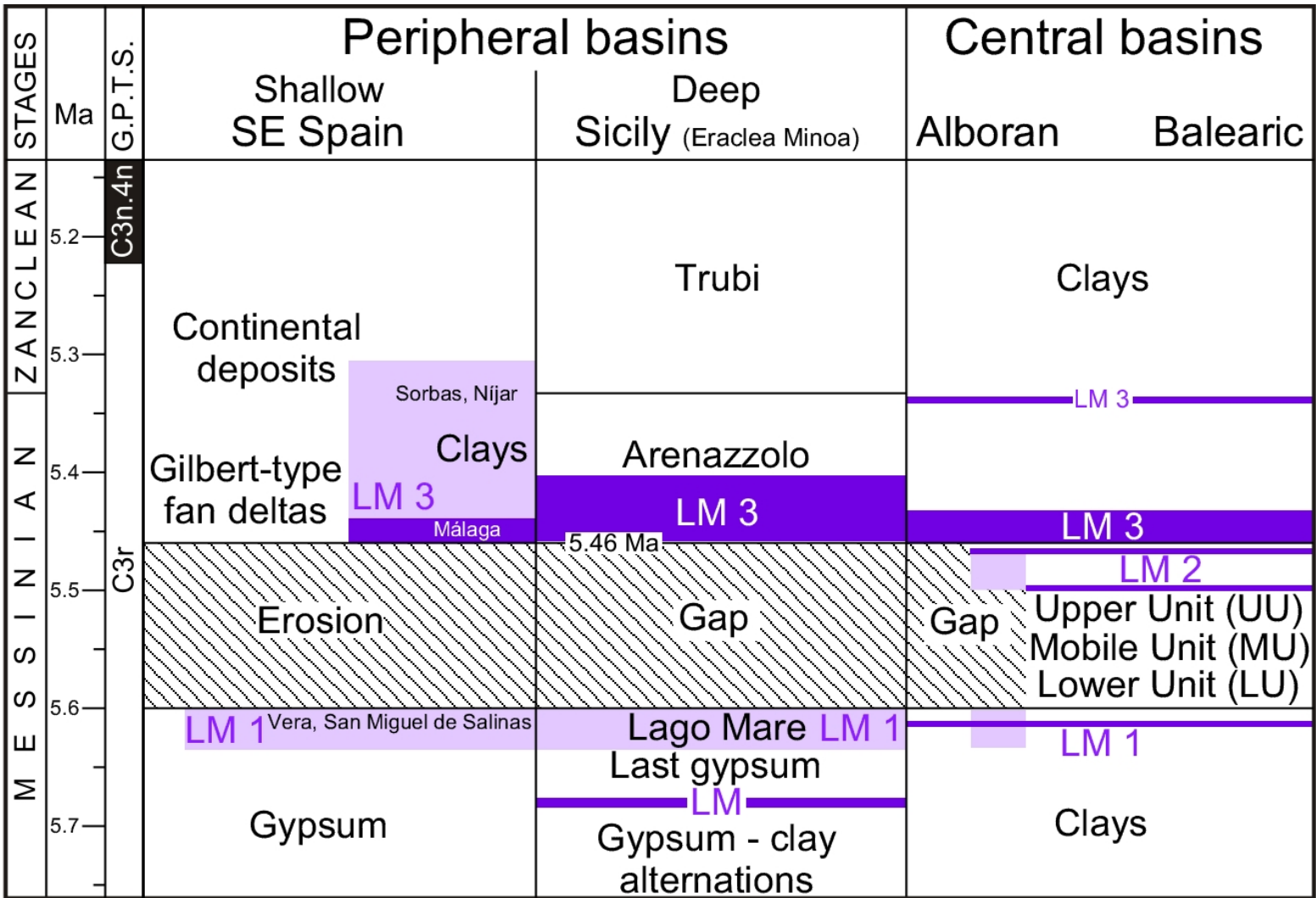

Influx of Paratethyan taxa (dinoflagellate cysts)

Expansion of Paratethyan taxa (molluscs, ostracods)

Fig. 8. Chronostratigraphic and biofacies interpretative significance of the Lago Mare events between 5.7 and 5.2 Ma.

Origin of data:

- $\quad$ southeastern Spain: Cita et al. (1980) for the Vera Basin, Aguire and Sánchez-Almazo (2004) for the Níjar Basin, Soria et al. (2008) for the area of San Miguel de Salinas, Guerra-Merchán et al. (2010) for the Málaga area, and Do Couto et al. (2014) for the Sorbas, Níjar and Málaga areas;

- Eraclea Minoa: Decima and Wezel (1971); Londeix et al. (2007), Popescu et al. (2009);

- Alboran Sea (holes 976B, 977A, 978A): Iaccarino and Bossio (1999) for Hole 978A, and this study for the three wells;

- Balearic Basin (Hole 134B): this study.

LM, Lago Mare biofacies. 


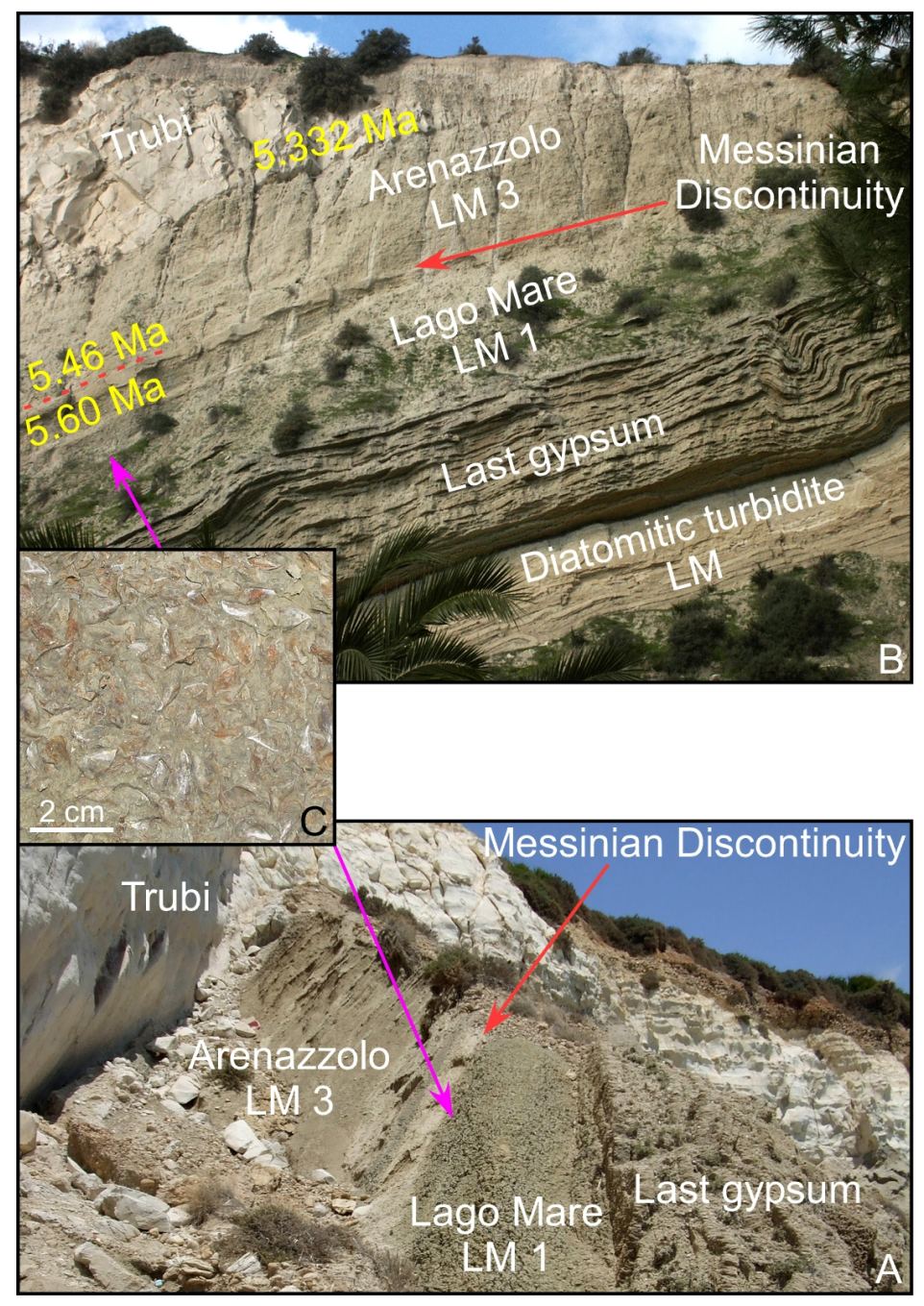

Fig. 9. Exposed Lago Mare units at Eraclea Minoa (southern Sicily).

A, Section showing the complete succession from the Upper Evaporites to Trubi.

B, Section showing erosion of the upper Lago Mare Unit and onlapping Arenazzolo Unit. C, Detail of the lower "congeria" bed (Lago Mare Unit 1). 

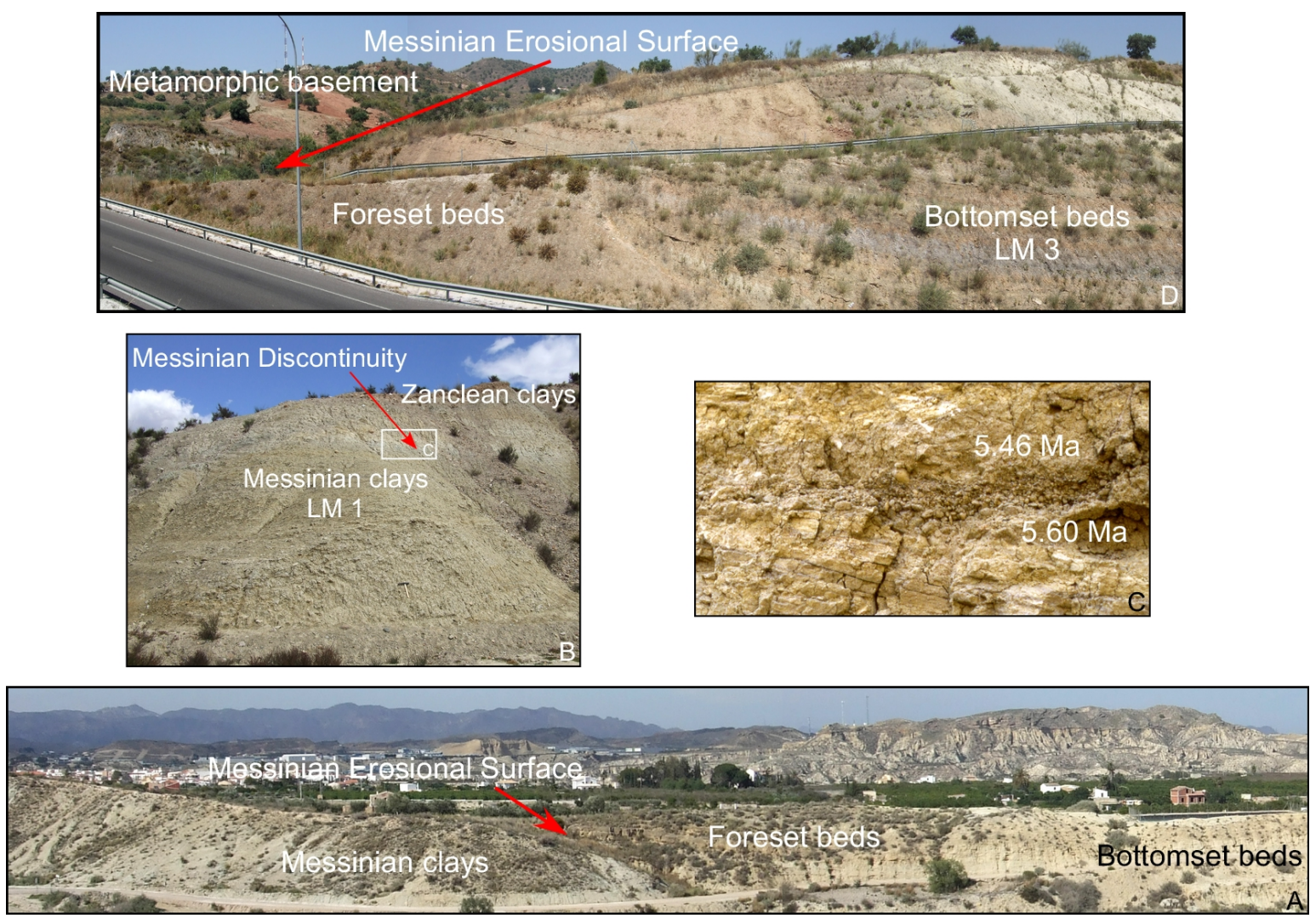

Fig. 10. Sections in southeastern Spain showing different examples of the Messinian-Zanclean contact with location of Lago Mare unit where present.

A, The Garrapancho section near Antas in the Vera Basin, where a well-dated post-MSC Gilberttype fan delta overlies the Messinian Erosional Surface.

$\mathrm{B}$, The Cuevas del Almanzora section in the Vera Basin where the Messinian Discontinuity is exposed.

$\mathrm{C}$, Enlargement of the conglomeratic Messinian-Zanclean contact in the Cuevas del Almanzora section.

D, The Río Mendelín section near Málaga where the post-MSC Gilbert-type fan delta includes a Lago Mare biofacies. 


\begin{tabular}{|c|c|}
\hline $\begin{array}{l}\text { Marine stenohaline taxa } \\
\text { (oceanic - outer platform) }\end{array}$ & \multirow{2}{*}{$\begin{array}{l}\text { Spiniferites delicatus } \\
\text { Spiniferites falcipedius } \\
\text { Spiniferites granulatus } \\
\text { Spiniferites lazus } \\
\text { Spiniferites pseudofurcatus } \\
\text { Spiniferites ramosus } \\
\text { Spiniferites ristingiensis } \\
\text { Spiniferites sp. } \\
\text { Tuberculodinium vancampoae }\end{array}$} \\
\hline $\begin{array}{l}\text { Impagidinium aculeatum } \\
\text { Impagidinium aquaeductum } \\
\text { Impagidinium paradoxum } \\
\text { Impagidinium patulum } \\
\text { Impagidinium sp. } \\
\text { Impagidinium sphaericum } \\
\text { Impagidinium strialatum }\end{array}$ & \\
\hline $\begin{array}{l}\text { Invertocysta lacrymosaa } \\
\text { Invertocysta tabulata }\end{array}$ & $\begin{array}{l}\text { Marine heterotrophic taxa } \\
\text { (inner platform - coastal) }\end{array}$ \\
\hline $\begin{array}{l}\text { Operculodinium israelianum } \\
\text { Operculodinium janduchenei }\end{array}$ & \multirow{10}{*}{$\begin{array}{l}\text { Brigantedinium cariacoense } \\
\text { Brigantedinium simplex } \\
\text { Brigantedinium sp. } \\
\text { Brown organic cyst } \\
\text { Isalndinium mintum } \\
\text { Lejeunecysta oliva } \\
\text { Lejeunecysta sp. } \\
\text { Polykrikos schwartzii } \\
\text { Selenopemphix armageddonensis } \\
\text { Selenopemphix brevispinosa } \\
\text { Selenopemphix nephroides } \\
\text { Selenopemphix quanta } \\
\text { Trinovantedinium sp. }\end{array}$} \\
\hline Pyxidinopsis pastilliformis & \\
\hline Spiniferites belerius & \\
\hline Spiniferites delicatus & \\
\hline Spiniferites hyperacanthus & \\
\hline Spiniferites lazus & \\
\hline $\begin{array}{l}\text { Spiniferites membranaceus } \\
\text { Spiniferites mirabilis }\end{array}$ & \\
\hline Tectatodinium pellitum & \\
\hline $\begin{array}{l}\text { Marine euryhaline taxa } \\
\text { (inner platform - coastal) }\end{array}$ & \\
\hline \multirow{13}{*}{$\begin{array}{l}\text { Achomosphaera alcicornu } \\
\text { Achomosphaera andalousiensis } \\
\text { Achomosphaera ramulifera } \\
\text { Bitectatodinium tepikiense } \\
\text { Capisocysta lata } \\
\text { cyst of Pentapharsodinium dalei } \\
\text { Homotryblium sp. } \\
\text { Hystrichokolpoma sp. } \\
\text { Hystrichosphaeropsis obscura } \\
\text { Lingulodinium machaerophorum } \\
\text { Melitasphaeridium choanophorum } \\
\text { Nematosphaeropsis labyrinthus } \\
\text { Operculodinium centrocarpum } \\
\text { Operculodinium sp. } \\
\text { Polysphaeridium zoharyi } \\
\text { Pyxidiella? simplex } \\
\text { Scrippsiella sp. } \\
\text { Spiniferites bentorii } \\
\text { Spiniferites bentorii truncata } \\
\text { Spiniferites bulloideus }\end{array}$} & \\
\hline & Brackish Paratethyan taxa \\
\hline & Galeacysta etrusca \\
\hline & Impagidinium caspienense \\
\hline & $\begin{array}{l}\text { Impagidinium globosum } \\
\text { Millioudodinium punctatum }\end{array}$ \\
\hline & Millioudodinium sp. \\
\hline & $\begin{array}{l}\text { Pontiadinium spp. } \\
\text { Pyxidinopsis psilata }\end{array}$ \\
\hline & Spiniferites bentorii oblongus \\
\hline & $\begin{array}{l}\text { Spiniferites bentorii pannonicus } \\
\text { Spiniferites cruciformis }\end{array}$ \\
\hline & Spiniferites spp. (Paratethyan) \\
\hline & $\begin{array}{l}\text { Spiniferites tihanyensis } \\
\text { Spiniferites validus }\end{array}$ \\
\hline & Freshwater algae \\
\hline & $\begin{array}{l}\text { Botryococcus } \\
\text { Concentricystes } \\
\text { Cymatiosphaera } \\
\text { Pediastrum }\end{array}$ \\
\hline
\end{tabular}

Table 1. Selected dinoflagellate cysts grouped according to ecological requirements (distality and surface salinity tolerance). 